\title{
A Review of Discourse Analysis in Literacy Research: Equitable Access
}

\author{
Lesley A. Rex, Mike Bunn, Bethany A. Davila, Hannah A. Dickinson, \\ Amy Carpenter Ford, Chris Gerben, Melinda J. McBee Orzulak, \\ Heather Thomson
}

University of Michigan, Ann Arbor, USA

\author{
Consulting Editors: \\ Janet Maybin, Open University, Milton Keynes, UK \\ Stephanie Carter, Indiana University, Bloomington, USA
}

\section{A B S T R A C T}

This review represents research employing discourse analysis conducted by scholars interested in literacy issues in education across the age span — preschool to adult—during the last 10 years. Drawing from more than 300 studies, we discerned that a common theme was understanding how the literacy education of all students can be successfully accomplished. We organized the review into two complementary sections. The first section highlights discourse analytic approaches taken to investigate: Whose literacies count? Which literacies count? The second section explains the contributions the studies made, organized according to five questions: What are literate identities, how are they constructed, and by whom? How are disciplinary knowledges, discourses, and identities constructed? How can schools provide students with access to school-based literacies? What are the shifting roles of literacy teachers and learners within and outside of school? How does discourse analysis research address movement within and across literacy sites and practices in a contemporary, globalized, and increasingly digitally influenced world?

$\mathrm{T}$ he discursive turn in philosophy and research epistemologies is well established, as are applications of discourse analysis in studies of literacy. Less well represented is the range and depth of this research. In this review, we offer one representation of discourse analysis research conducted by scholars interested in literacy issues in education across the age span (i.e., preschool to adult) over the last 10 years. Our review builds upon earlier reviews (e.g., Poole, 1990). We searched for research disseminated outside of as well as within education, and by researchers whose primary field was other than education. Our representation is sourced by most frequently cited peer-reviewed studies, journals, chapters, and books on literacy and discourse found in eight overlapping research databases: WorldCat, JSTOR, ProQuest, ScienceDirect, Wilson, Dissertations Abstracts, ERIC, and ISI Web of Science. Our aims were to discover which literacy issues have been investigated through discourse analysis and for what purposes, how scholars have applied discourse analysis in their research, and the cases researchers have made for the pertinence of discourse analysis in literacy studies.

In our review we made a heuristic distinction between studies of discourse processes and studies employing discourse analysis. Studies of discourse processes employ a wide range of perspectives and methods but not necessarily discourse analysis as that term has come to be defined in recent discussions of discourse analysis (e.g., Blommaert, 2005; Bloome, Carter, Christian, Otto, \& Shuart-Faris, 2005; Bloome et al., 2009; Gee, 1999; Howarth, 2000; Johnstone, 2001; Mills, 2004; Paltridge, 2006; van Leeuwen, 2008; Woods, 2006). Focusing on studies employing discourse analysis led us to exclude large bodies of research about discourse processes. For example, we excluded a rich corpus of research by scholars in cognitive science and cognitive psychology about individual readers' discourse processes (see Graesser, 
Mills, \& Zwaan, 1997) and text processing (e.g., Wolfe $\&$ Goldman, 2005), as well as scholarship about group language for thinking and learning (e.g., Mercer, 2004). Through axial coding of the more than 300 studies that remained, we discerned that a prevailing theme dominated the purpose of discourse analytic approaches to literacy and education over the last decade-equitable access.

The complexity of the concept of "equitable access" was highlighted in a recent volume of the Review of Research in Education (Gadsden, Davis, \& Artiles, 2009) centered on risk, schooling, and equity. As argued by Gutiérrez, Morales, and Martinez (2009) in that volume, conceptions of equitable access need to move beyond deficit readings in education of cognitive and language potential and the dichotomous modes of thought that maintain them. As we describe in this review of research, one of the contributions of discourse analysis studies of literacy in education is problematizing how equity and access have been defined in part by deconstructing traditional binaries_-for example, successful/ unsuccessful; abled/disabled; capable/deficit; central/ marginal. As part of this problematization, many of the studies conceptualize literacy as complex, dynamic processes and actions implicated by social and political investments.

That equitable access to literacy education is a dominant theme in discourse analysis studies of literacy and education should come as no surprise as it reflects the current migration and relocation within and across regions and countries of millions of students and their families. Physical migration, accompanied by economic, technological, political, cultural, scientific, and educational globalization (Altbach, 2005) and by increasingly diverse and accessible communication and media on the Internet, has contributed to a prevailing sense of local and global dislocation, a condition Bauman (2000) termed liquid modernity. Bauman has argued that this condition requires a rethinking of the concepts and frames with which we describe individual human experience and joint undertakings. Although not necessarily referencing Bauman, discourse analysis studies of literacy in education can be viewed as responding to the condition of liquid modernity by generating new theorizations of literacy phenomena and education problems, making them visible for study, raising new research questions, and generating creative designs and methodologies to explore and understand these phenomena.

To address a wide array of contributions, we selected discourse analysis studies by linguists, discourse scholars, social scientists, education researchers, and teacher researchers, who contributed a variety of perspectives as well as insights on how to approach the issues of equity and access in and through literacy education. Our quest for variety was shaped by Bloome and colleagues' (2009) explication of the three directions in which discourse analysis studies in literacy classrooms should look for their theoretical principles and epistemological assumptions-to related disciplines, to the nascent history of other discourse analysis studies, and to the social "problem" being addressed. Therefore, in addition to studies that claim discourse analysis as their approach, we included research in which discourse analysis was clearly undertaken though not explicitly named as lens or method (e.g., Carter, 2006). Before presenting the review of research, we define key terms we used in conceptualizing the review.

\section{Definitions of Key Terms Framing the Review}

We begin by defining three terms key to discourse analysis studies of literacy education: discourse, discourse analysis, and literacy. We define these terms as a trope for highlighting the variation of definitions and conceptions found in the research we reviewed.

The majority of such studies we reviewed construe two interrelated levels of discourse-more global aspects and more local contextually situated aspects (Erickson, 2004). More global analyses examine societal, institutional, and historical discourse(s) whereas more local analyses tend to be site-based descriptions of discourse, quite often, but not limited to, languagein-use. Methodologies analyzing interactions between global and local discursive forces have also gained prominence, as a way of relating social theories with situated events. Consistent with all three approaches is the view that discourse is culturally based; reflects and constructs reality and meaning, power, identity, social position, and knowledge; and that the discursive medium does matter.

For our review purposes, we define discourse as instances of communication through language. During these instances, people draw upon knowledge about language to use language to accomplish something in the world. This view of discourse includes language modalities beyond traditional speaking and writing, such as signing and digitization. As a verb, discourse refers to interactional activity creating meaning and relationship, what has been referred to as language-in-use (Rex $\&$ Green, 2007) and discourse-in-use (Bloome \& Clark, 2006). Discourses we understand to be conventional ways of communicating that generate and are generated by conventional ways of thinking.

We take the view that discourse analysis is a theoretical conceptualization of a phenomenon, an epistemological approach to understanding and representing it as well as a methodology, or logic of inquiry, for answering a wide variety of literacy-related questions (Gee 
\& Green, 1998). For example, Bloome et al. (2009) defined discourse analysis not as a set of methods per se but as a set of ways of "seeing" language and literacy events in classrooms. In discourse analysis studies the construct of discourse is central to both the theoretical framing and to the logic of inquiry employed (Bloome et al., 2009). Within this approach to discourse analysis, questions about literacy and education are answered by examining dynamically and contingently interrelated aspects of the structure, function, and communicative production of discourse.

We define literacy as a discursive phenomenon that is situated culturally, historically, and spatially (and as such is often expressed in the plural form literacies). Such a definition of literacy(ies) eschews monolithic, autonomous, and decontextualized descriptions of literacy activities, practices, events, and processes. As a situated phenomenon, literacy(ies) can be described at three units of scale-macro, micro, and meso.

At a macro level, researchers employing discourse analysis concern themselves with global educational policy, institutional procedures, and schooling curriculum as sites in which discourse practices determining literacy also determine right of access, right to resources, and what constitutes schooling achievement. Analysis at this scale attends to macro literacy discourses, in keeping with Gee's notion of conversations about literacies in vogue at particular historical times (Gee, 1999; cf., Fairclough, 1995).

Analysts interested in local discursive practices focus on interactions and literacy practices in specific classrooms, schools, and other sites of literacy production. This micro scale focuses on situated literacy discourse in use.

Meso distinguishes those literacy discourses that become recognized through local situated practices as genres or discourse types particular to cultural, institutional, or social contexts, as borrowed from retheorizations of traditional genre theory by linguists (e.g., Christie \& Martin, 2005) and compositionists (e.g., Devitt, 1993; Johns, 2002). Meso discourse genres spatially locate outside of school as well as inside, in community groups such as families, workplaces, churches, and after-school programs; in administrative and policy venues such as state, school board, and district meetings; and, in stakeholder gatherings such as PTO and gaming groups.

The discourse transcribed and analyzed in the brief segment that follows illustrates these macro, micro, and meso frames so as to demonstrate their complementary and interpretive strength.

A few days into reading Hemingway's The Sun Also Rises, a teacher seizes the opportunity to make a point about writing to his eleventh-grade class. They have read aloud one of Hemingway's page-long sentences and the students are surprised that the author could get away with connecting so many clauses with "and." Their former English teachers have not allowed such breaking of the rules. The teacher, Stan, addresses the nature of "rules" in writing. ${ }^{1}$

1. Stan: What have your teachers told you before about writing? (Students call out rules for writing, and Stan lists them on the chalkboard.)

No "ands" or "buts" or "because" to start a sentence

5 paragraphs

No "I" or "you"

Thesis is last sentence of the 1st paragraph

One topic sentence for each paragraph

No contractions

2. Stan: Well, we could probably go on and on, but you know what (.1) the simple fact is

(Crosses out the list with a giant X) [that none of these are rules.

3. Jacob: [All of these are rules.

4. Solice: (.02) Oh, they're just their own rules, too.

(Stan lifts his arms to shoulder height to perform an upper body shrug at Solice.)

5. Mary: Oh, wow.

6. Robert: They're rules on the (state standardized test).

(Seven students laugh)

7. Stan: (.5) There are no hard, fast rules there. Sometimes it's good to do that, sometimes maybe it's not (1.5) [OK?

8. Monica: [I like this class $=$

9. Janine: $=$ Me too $=$

10. Mary: = I know =

(Five students laugh)

11. Stan: What we're going to do is we're going to be writing things that... doesn't necessarily... where you don't have to put all this stuff in there. OK? We'll talk a little bit more about it. I just wanted to introduce you to how I see writing. And sometimes good writers don't use that stuff up there, they don't follow those things. Maybe sometimes they do, it depends on what you're writing. If you're writing a love letter to, to your boyfriend or girlfriend, is it going to be in five paragraphs?

12. Four students: [No.

[Uh-uh

13. Stan: No, probably not, probably not. OK. Good. We'll get back to some of these rules or nonrules....

Discourse analysis of this instructional interaction at a micro level represents differences in Jacob's, Solice's, and Robert's responses to their teacher. Each response signals the sense each student is making of Stan's pronouncement. For Jacob the authority of the listed rules is unquestionable, whereas Solice moves in her understanding to where Stan is pointing-these rules belong to her previous teachers, while Robert provides another perspective: evaluators of the high-stakes exit test adhere to those rules. At the same micro level of meaning 
making we can observe how Stan shrugs in response to Solice's declaration. Mary's and Robert's responses as well as Stan's next spoken utterance indicate what ethnomethodologists would refer to as the joint social sense being made (if not agreed to): rules of writing are not absolute or a priori.

Stan and the students' interaction can also be viewed as an invocation of macro discourses. The speakers are referencing conventional socially established discursive ideologies for doing school, teaching and learning, and being students and teachers. Even as they construct a local situated reality for their classroom, they draw from these macro discourses-for example, about testing, the role of literature in teaching writing, and assessments of teachers' and students' competence-to discuss and construct identities and power relationships (Blommaert, 2005; Gee, 2000b).

An essay genre habitually located in English classrooms is central in this interaction: the five-paragraph essay. Even though the form has been challenged repeatedly for encouraging reductive thinking with its simplistic organizational structure (Wesley, 2000), the five-paragraph genre remains ubiquitous in U.S. high school English curricula. Stan's challenge of the rulebased meso discourses that teach this genre is not unusual, nor is he operating as a lone challenger. In referencing the practices of "good" writers he draws upon the meso discourses of literacy practice-writing like a "real writer"- -he engaged during his National Writing Project institute experience the previous summer.

This framework of macro, micro, and meso levels of discourse analysis allows us to bring into view and interpret what is occurring as speakers invoke the rights and responsibilities of English teachers as those who set the rules for how to write. Stan positions himself as a writing teacher in relation to other English teachers as well as positioning his perspective on the rules of writing in relation to theirs. He positions by opposing, and in so doing constructs a classroom world identified through its opposition. Stan appears to mean that literacy practices in this classroom will be distinguished by their resistance to those of former teachers and students' school-based writing experiences. When he marks out the rules on the board with an X, Stan replicates the slashing arm movements Jane had used earlier in the class to describe her previous English teacher's marking of her essay's run-on sentences. Likewise, by referencing written genres other than the five-paragraph essay, Stan signals a world of writing superior to the curricula in prior courses; his is a writing world in competition with the high-stakes test world, whose discourses embrace Hemingway's stylistic choices.

This brief discourse analysis of two minutes of classroom literacy instruction raises questions about equity and access to and through literacy practices, including
Which literacies count? And, whose literacy(ies) count? These two questions are discussed at length later in this review of studies over the last 10 years. The research reviewed builds on long-standing programs of research and scholarship employing discourse analysis that challenged conventional definitions of literacy and the literate person (e.g., A. Luke, 2003). Scholars with this intent located in subject matter disciplines have been concerned with making the literacies in those subject matters accessible (e.g., Lemke, 1995). They, as well as scholars who do not place themselves within a specific subject matter, disrupt autonomous definitions of literacy that carry social and academic capital (e.g., Street, 1995). Some have been more concerned with literate genres (Christie \& Martin, 2005) while others with the teaching and learning practices that produce them (Bloome, 1985; Cazden, 2001; Green \& Wallat, 1981).

Corresponding scholarship has explored how students and teachers develop shared understandings about knowledge and literacy (Edwards \& Mercer, 1987, 1989). Literacy outside of schooling has interested scholars who sought to raise the importance and status of such genres and practices (e.g., Heath, 1983). Many of these researchers were intent upon informing ways for students least well served by schooling to gain access to school-based literacy (Gee, 1996, 2000a). These programs of scholarship provide foundational concepts, methodologies, and purposes that have influenced the study of literacy through discourse for the researchers whose work we highlight in this article.

As noted earlier, reverberating throughout these programs of study and the more than 300 studies we reviewed were two implicit questions: Whose literacies count? Which literacies count? These questions are key because issues of equitable access require considering who is exercising literacy, for whom, and with what consequences. Who is not a single, stable entity. The "who" in "Whose literacies count?" can be a selfassigned identity held to by its owner, a social role the owner assumes for a particular purpose, or a public label assigned for an institutional function, among others. In the reviewed studies, researchers are concerned with the people whose literacies do not count in the places where all citizens should have educational, civic, political, or cultural traction. The researchers are also concerned with describing and understanding the literacies, or literate discursive practices, that do count in those places and the consequences they have for those who attempt to engage them.

The questions Which literacies count? and Whose literacies count? are interrelated. Separating the identities of those engaging in literate practices from the literate discourses in which they are constructing themselves is like determining a beginning and ending for a Möbius strip. Nevertheless, for heuristic purposes we 
treat the questions Whose literacies count? and Which literacies count? as separate categories of inquiry to resist conflating identity with practice. We also separate these categories to draw attention to discourses associated with particular groups and to distinguish them from discourses attached to particular literacy definitions, practices, and sites.

\section{Whose and Which Literacies Count?}

We have organized the review into two sections to provide two representations of the literature. The two are meant to be read in dialogue with each other so as to avoid a single reading that could contribute to an essentializing, ahistorical view. In the first section, we highlight discourse analysis studies that address two foundational questions that surfaced in our axial coding: Whose literacies count? and Which literacies count? In the second section we highlight discourse analysis studies which address the following five questions (which were also revealed through our coding):

1. What are literate identities, how are they constructed, and by whom?

2. How are disciplinary knowledges, discourses, and identities constructed?

3. How can schools provide students with access to school-based literacies?

4. What are the shifting roles of literacy teachers and learners within and outside of school?

5. How does discourse analysis research address movement within and across literacy sites and practices in a contemporary, globalized, and increasingly digitally influenced world?

\section{Whose Literacies Count?}

Research that fits this category was concerned with how educational structures and those in positions of authority are consequential for literacy learners. "Whose" referred to individuals/institutions at the macro, micro, and meso levels (and usually a complex mix) depending on the area for investigation. Individuals could be children, youth, adult learners, teachers, literacy consultants, policymakers, or scholars. Institutions were organizations established for or invested in literacy education. These institutions have been community organizations, churches, nonprofit or for-profit schools or professional development institutes, departments of education in universities, or governing bodies.

Many studies we reviewed used discourse analysis as a way to determine which individuals' literacy practices were sanctioned by schools and other institutions and whose were relegated to the periphery. Though the contexts of their research vary widely, a number of scholars working in this area were invested in finding ways for nontraditional or nondominant literate identities related to gender, ethnicity, social class, cultural orientation, or race to gain visibility and respect within traditional institutional settings.

Essential to the argument for the access of students' nontraditional or nondominant literate identities was the interrogation of ideological frameworks that positioned them out of the mainstream. Researchers in this area highlighted the ways in which literacy practices, literacy research, and literacy policy were informed by particular sets of ideas, aims and institutional interests, using discourse analysis to identify the ways in which these frameworks-sometimes subtly, sometimes explicitlyinfluenced self-interested decisions about literacy.

The particular foci of study varied, from how local literacy practices shaped readers' responses to texts in ways that reinforce dominant social relations and ideologies (meso) (Young, 2000), to the notion of repairing a conversational turn as an ideological practice that reflects cultural authority (micro) (Razfar, 2005), to the ways in which discourses around literacy policy debates reveal political and ideological interests (macro) (Blunt, 2004; Edwards \& Potts, 2008). Yet many of these studies had in common a focus on power structures and their relationship to literacy practices so as to privilege particular people, groups, or institutions.

The classroom has been the site for much of this discourse analysis literacy research, bringing together power dynamics between teachers and students with schooling discourses that sometimes conflict with those of students' homes or communities (Love, 2000). Moni, van Kraayenoord, and Baker (2003), for example, studied the discourses of assessment in two Year 8 English classes at two state high schools in Queensland, Australia, noting how teachers' and students' classroom assessment discourse was complex, unstable, and left little room for student agency. Taking an ethnographic approach, combining transcripts of interviews with video of classroom interactions, Moni and colleagues used a composite of discourse analysis approaches that included critical discourse analysis (Gee, 1999), sociolinguistic analysis (O'Connor \& Michaels, 1993), and discursive psychology (Potter, 1997; Potter \& Wetherell, 1994) to study feedback sessions on students' work. They found that these sessions positioned teachers as "audience, marker, commentator, corrector, all-round expert and guardian of students' work," (Moni et al., p. 79) while students "were positioned by the teachers as receivers of information" and their talk was "seldom acknowledged as important and/or salient" (Moni et al., p. 79). 
Students were positioned either to align their own discourse more closely to the teachers' expectations or to develop an increasingly negative attitude toward assessment, which they did-a move that generally affected their achievement negatively as well. In this case, the power relations and discourses served to reinforce students' subordinate position to the teacher and to silence students' own sense of the purpose and success of their academic work. The researchers asserted that the descriptive results argue for the importance of developing understandings of literacy-based assessment from the perspectives of all classroom participants.

At stake in the Moni et al. (2003) study-and in other research in classrooms-was the unveiling of largely unquestioned ideological assumptions that determine whose literacies should count when officialin this case the teachers'-curriculum, pedagogy, and assessment was seen to counter students' literacy learning. By working to expose and interrogate these assumptions, scholars raised questions about whose interests were being served in various contexts, and why and how these sites might respect, accommodate, and productively incorporate nondominant orientations toward literacy and literacy learning.

Scholars working to raise questions about whose literacies count also critiqued the ways in which the literacies of particular groups were left out of sanctioned literacy practices, particularly in formal educational settings. Using discourse analysis, they have studied home- and school-based literacy practices (Rogers, 2004) as well as the literacy practices of subsets of disadvantaged or underachieving students (Hinchman \& Young, 2001) to raise questions about how certain literacies were sanctioned and others were rendered invisible, or deviant, and so reinforced popular stereotypes about these groups as deficient.

For example, Dworin and Bomer (2008) used two different approaches to critical discourse analysis: one derived from Gee (2005b) and the other from Fairclough (1995) and Rogers, Malancharuvil-Berkes, Mosley, Hui, $\&$ Joseph (2005) to critique the ways in which a popular professional development text for U.S. teachers, A Framework for Understanding Poverty (Payne, 2005), reinforces assumptions about those living in poverty and "enlists readers' participation in deficit discourses about the poor" (p. 101). In a sentence-by-sentence discourse analysis, the authors demonstrated that the text affirms and celebrates middle class students while depicting poor students as deficient and the literacies and discourses that they bring to the classroom as detriments to an orderly, successful school.

By using a diverse array of strategies for critiquing the text's discourse, Dworin and Bomer not only described and interpreted, but also explained how the text's discourse constructs particular social worlds.
They claimed that these discursive moves reproduce discriminatory power structures, and they argued that teachers and students must develop a discourse "that sees students, whatever their background, as competent, inventive, worthy, and respectable" (p. 103).

In addition to examining microscale classroom discourse and macroscale professional development texts to observe "Whose literacies count?" attention has also been given to mesoscale discursive activity. For example, Gebhard (2002) framed her Critical Discourse Analysis (cf., Fairclough, 1995) of reading and writing instruction and a focal student writer's performance in a Silicon Valley elementary Web magnet school in California, through the ideological framework of "fast capitalism" (pp. 16-17). Through the discourse analysis of the experiences of this student and others (all labeled "limited English proficient") and their families, she demonstrated how literacy practices particular to the school, meant to "produce an Information-Age savvy workforce" (p. 18), "inadvertently constrained the efforts of second language learners to acquire academic literacies" (p. 15) and made it difficult for these students to be classified as successful or high achieving. Gebhard found that these students were particularly vulnerable to being characterized as "not Web material" (p. 15) as they competed for limited spots in the school because of the ways that the curriculum positioned their home literacy practices as clashing with those valued at the school. In addition, she found teachers' understandings of learning, literacy development, and multilingualism resulted in practices that sometimes inaccurately cast limited English proficient students as remedial or learning disabled, jeopardizing their position in the school community.

As well as drawing attention to privileged literacies and their consequences for individuals and groups, the application of discourse analysis illustrated how these literacies served the interests of those in power and how their dominance reinforced and perpetuated social and political hierarchies. Moni et al. (2003) illustrated how teachers inadvertently undermined the achievement they were working to assess through their discursive constructions of assessment. Over time, the teachers discursively positioned students to assess their own writing and academic performances in ways that limited and discouraged their potential engagement in literacy learning.

As researchers exposed patterns of discrimination and inequitable approaches to literacy practices through such studies, they also critiqued the conditions that produced those practices, offering recommendations for change. In addition to the aforementioned studies, for example, Cairney and Ashton (2002) applied discourse analysis to "mismatches" between home and school literacy practices of diverse families and argued 
that "greater effort on the part of the school is required to ensure students' success" to challenge the notion of home literacies as "deficit" (p. 305). Such critiquesof the intended and the inadvertent-also opened the door for research that explored ways in which diverse literacies could be more effectively incorporated into educational settings.

\section{Which Literacies Count?}

Researchers have used discourse analysis to investigate issues of equity related to the authority of types of literacy definitions, literacy practices, and sites of literacy having to do with access. They revealed this authority to describe how it could constrain or enable opportunities for literacy learning. Often in this research, discourse analysis connected macro-level literacy ideologies to microanalysis of literacy practices and brought attention to meso discourses-genres/forms of literacy.

For example, Olson (2007) analyzed circulating discourses to uncover how narrow, test-driven definitions of literacy could limit students' opportunities to learn from more informed curriculum. Carrington (2005) focused on texting as a literate form positioned in the media as substandard, so that by extension those who text, especially for school-related purposes, were also positioned as "less than." She lexically classified the discourse in two newspaper articles to illustrate how "txting" was positioned throughout as "the abnormal intruder" (p. 167). Rogers and Mosley (2006) applied a Whiteness theoretical framework to ethnographically examine multimodal dimensions of classroom racial literacy with white working class children.

Following Carspecken's (1996) reconstructive analysis approach, Rogers and Mosley open coded ethnographically collected data to select salient transcripts and artifacts for discourse analysis. Their multimodal discourse analysis created a description of how the children and their teacher engaged a critical literacy curriculum to develop the children's racial literacy, in a way that represented "the complexity of the construction of race" and "the hybrid nature of emerging understandings around race" (p. 483).

In another study, Newman (2005) argued the theorization "multiliteracies" (see New London Group, 1996) is most conceptually accurate to label genres of social literacy exercised outside of school. Newman made his case by presenting the results of his ethnographically approached genre analysis of an inner city rap crew's improvised round-robin rhyming. He determined that "the practices and forms of the [rap] ciphers are tightly bound up with their creators' ideologies and that when holders of incompatible ideologies interact in rap, generic conflict results" (p. 399). Common to these discourse analysis studies, among others, were concerns with current ways of valuing literacy; of descriptively labeling literacy such as essay literacy, racial literacy, and multiliteracy; and of theorizing literacy.

Scholars interested in what counts as literacy commonly engaged multiple analytic lenses to focus on a particular aspect of literacy regarding equity and access in literacy interactions, with the understanding that no single theoretical lens or methodology could represent the complexity of literacy's manifestations. For example, Van Sluys, Lewison, and Flint (2006) combined three lenses in their microanalysis of one elementary school classroom conversation between two girls in a literacy activity: grounded theory, critical literacy frameworks (Luke \& Freebody, 1997), and critical discourse analysis. They argued that multiple lenses were needed to understand data and to provide ways to "take action" in relation to study of critical literacy practices.

Another direction taken by discourse analysis studies was to observe how discursive practices within the classroom influenced the construction of academic literacy knowledge (Rex, 2006a). Edelsky, Smith, and Wolfe's (2002) study applied Brown, Collins, and Duguid's (1989) and Gee's (1999) constructs for communities of practice to frame literature study as an artificial, "ersatz," activity as engaged in by teachers and students in schools. They argued that teachers promoted ways of talking about literature in school by attributing them to the out-of-school practices of the literati while framing and infusing them with the culture of school. Edelsky et al., as do Clarke (2007), Moita-Lopes (2006), and Rogers and Mosley (2006), strove to link the micro with the macro by framing their research with theories of how discourses in the classroom relate to those from other sites, sources, and times.

A central theoretical and methodological theme in discourse analysis research exploring "What counts as classroom literacy knowledge?" is the conceptualization of culture as the source of values, beliefs, expectations, and norms or practice. Areas of research about culturally based patterns of talk related to ethnicity or countries of origin have expanded understanding and respect for the role of cultural ways of speaking learned in the home (e.g., Medina, in press). For example, Minami (2002) employed narrative discourse analysis to illustrate how Japanese mothers shaped their children's culturespecific discourse styles in developing oral literacy that should be considered in determining classroom literacy knowledge-building practices. Studies concerned with culture used discourse analysis to point to complex interrelationships between specific culture-based discourse patterns and interactions and the literacies that count. This research illuminated unexpected, complicated, and sometimes dilemmatic distinctions between which literacies are valued, where, and with whom.

The issue of value (which is implicit in the question "Which literacies count?") was often linked by 
researchers to the locus of power or privilege. Literacy researchers frequently used discourse analysis to foreground issues of authority and power in school-related interactions or strategies that construct what counts as literacy. They explored how the authority of certain practices, discourses, and ideologies could constrain or promote classroom opportunities to learn particular knowledge (e.g., Johnson, 2002; Moje, 1997). Discourse analysis enabled researchers to unpack situated, multiple power relationships in determining what counts as school literacy at home (White, 2002), as competent literacy practice (Love \& Hamston, 2001), and as "good" or "bad" English in school and home spaces (e.g., Godley, Carpenter, \& Werner, 2007) while contrasting schooling ideologies about literacy with local "grassroots literacy" (Blommaert, Muyllaert, Huysmans, $\&$ Dyers, 2005).

In summary, the epistemological question "What counts as literacy?" was interpreted through discourse analysis as two areas for study: Whose literacies count? and Which literacies count? These questions oriented discourse analysts interested in equity and access to a constantly moving target. What counts as literacy is historically, socially, and politically always in flux. Thus, research to describe and promote productive educational change has necessarily shifted to remain focused on what counted as literacy at that time as informative and viable knowledge. To explore and interrogate definitions, practices, and sites of literacy in relation to questions of access and equity, discourse analysts called upon wide assortments and combinations of theoretical frameworks and methodologies.

As illustrated in the studies mentioned earlier, discourse analysis of literacy in education often involves some combination of critical, sociocultural, and cognitive lenses with ethnographic, sociolinguistic, and grounded theory methods. The sections that follow reflect five categories of contributions made by the discourse analysis research we encountered as we prepared this review.

\section{What Are Literate Identities, How Are They Constructed, and By Whom?}

Scholars have called on discourse analysis to illuminate the ways social identities were shaped by and tied to literacy practices (see Moje $\&$ Luke, 2009) for a review of literacy and identity research). Discourse analysis research has offered descriptions of and insights into how literacy and identity were mutually and recursively constitutive and directly related to equity and access. In such studies, researchers interrogated processes of positioning the self and others as literate learners. Based on the results of their studies, they challenged dominant, long-standing beliefs about the literate potential of various identities (often associated with a deficit view of student performance and achievement) and interrogated the social construction of identities through and related to literacy.

Reacting against the ways many macro educational discourses treat both literacy and identity as singular, all of the studies represented in this category not only assumed the multiplicity of both constructs (literacy and identity) but also illustrated the ways in which students move in and out of various subject positions while interacting with varying literacies. Much of this research not only acknowledged contradictions and conflict within multiple literacies and identities, but also sought out these tensions as rich sites for research on literacy, identity, and ultimately the ways they contribute to or interfere with equity and access.

Working to reconceptualize educational discourses about literacy and identity (also called literate identities), scholars have called on discourse analysis to interrogate the relationship between literacy and identity (EganRobertson, 1998; Godley, 2003), challenge commonly accepted perceptions of literate identities (Bausch, 2007; Ivanič, 1998; Jones, 2006; Martínez-Roldán, 2003; Weinstein, 2006; Wohlwend, 2009), and understand the role of ideologies and contexts in students' constructions of literate identities (Alvermann, Young, Green, \& Wisenbaker, 1999; Peterson \& Calovini, 2004; Richardson, 2007).

Discourse analysis studies have interrogated and nuanced the liminal space of seeming binaries or conflicting identities, arguing (both explicitly and implicitly) against a single, commonly accepted or essentialized understanding of either literacy or literate identities. For example, Godley (2003) used discourse analysis to explore the negotiation of gendered identities in an 11thgrade honors English classroom to understand and illustrate the multiplicity and enmeshment of students' identities during literary discussions. Godley provided close analysis of the identity enactments of two students-one male and one female - to show that students could occupy conflicting subject positions (such as strong learner vs. athlete and female vs. debater). She argued that educators need to approach literacy learning as "not only an academic endeavor but also a negotiation of social identities" (p. 285). This, she suggested, creates new potentials for educators and students to open up spaces for literacy and identity development.

Although Godley (2003) argued that students can concurrently perform multiple, recognizable identities, several other researchers used their results to argue that students' identity and literacy practices may be even more complicated or layered. In Bausch's (2007) study of a third-grade male student, she used discourse 
analysis to reevaluate what counts as productive literate identities and practices. Her research countered previous studies that had suggested a conflict between gender (specifically the male gender) and literacy practices. Her analysis of classroom book talk illustrated the ways in which the male student "transforms the shape of literacy as he constructs his identity" (p. 200). She argued that despite the initial appearance of noncompliance or nonparticipation, the student was operating within commonly recognized forms of book talk, but also subverting those meso discourses to allow for other-specifically gendered-identities as well.

Similarly, Jones (2006) examined class-based attitudes, behaviors, and identities traditionally viewed as nonschool congruent. Through her work with eight, second-grade girls, Jones used discourse analysis to explore the link between language and identity, arguing that teachers must find ways to make use of traditionally marginalized language practices (in this case, those related to gender and class) in a way that will welcome students into academic literacies by first valuing their home language practices. In other words, educators must do the work of making connections between seemingly conflicting identities if they hope to increase access for students with marginalized language and literacy practices.

For Alvermann et al. (1999), one of the ways of addressing potential conflicts among literate identities is through an interrogation of context. These researchers used discourse analysis to study the ways that operating a book club outside of the traditional academic setting —in a public library-offered new possibilities for students to try on different literate identities without some of the constraints of schools (their peers and teachers' "readings" of their literacy practices). However, the researchers also argued that although a change in context was liberating for many of the students, others still felt constrained by the powerful macro discourses surrounding literacy activities. Their findings suggested that students must negotiate between their experiences and ideologies when enacting literate identities.

Richardson's (2007) discourse analysis study also shows the sophisticated literate identities of students outside of academic settings. She illustrated contradictions within ideologies associated with a specific literacy practice-the critical literacy of young, African American females "reading" hip hop texts (rap videos). Richardson examined the discursive means by which the women in her study negotiated and integrated rap texts with their experiences. She argued that these women were critically literate in a space that often is marginalized by education (and society), suggesting that it is possible to simultaneously challenge and reproduce "Anglo-American gender ideologies" (p. 806) by participating within hip hop literacies.
Although the studies previously mentioned in this section have largely focused on students' positioning of themselves as literate, other researchers have illustrated the importance of understanding the ways in which students were positioned by others (Dagenais, Day, \& Toohey, 2006; Nichols, 2002; Rogers, 2003; Woude \& Barton, 2003). Dagenais et al. highlighted the importance of teacher expectations to the construction of students' literate identities when they followed one multilingual student into multiple classrooms, observing the ways that her literate identity was constructed in situated moments of literacy practices. Some teachers positioned the student as capable, while one teacher positioned her as at risk-the difference, according to the authors, resided within the competition between macro discourses about successful literacy learners (such as participation in full-class discussions and independent learning) and micro and meso discourses in which educators put aside expectations associated with macro discourses to examine what was occurring in the moment and in the specific literacy environment of their classroom.

Nichols (2002) and Woude and Barton (2003) took their analyses outside of the classroom to understand both the influences on and possibilities of parents' positioning of their children in terms of literacy. Nichols argued that discourses of gender and childhood were extremely influential to the ways that parents talked about, responded to, and managed their children's literacy practices and identities. According to their analysis, the parents worked to reproduce dominant discourses about literacy and identity.

On the other hand, Woude and Barton's research illustrated how parents' positioning of their children can productively counter dominant discourses about children's literate capacities, by describing how parents of children with language delays positioned their children as competent language learners. Both studies argued the importance of this positioning to the literacy learners themselves and suggested possible spaces for intervention to increase equity for students commonly positioned as less literate than their peers.

When considered collectively, the research represented in this section works to understand the intricate layering and lamination of literacy and identity. Perhaps most importantly, the research prompted calls for discourse analysis to not only illustrate how dominant ideologies can be and are challenged by students, parents, and educators but also highlight the importance of contradiction to increasing literacy equity and access. More specifically, this research expanded on the increasingly common belief that literacies and identities are multiple to also argue that contradiction among literate identities may be a means of or space for agency, creation and, when warranted, subversion. 


\section{How Are Disciplinary Literacy Knowledges, Discourses, and Identities Constructed?}

Discourse analyses of disciplinary discourses and content area literacies show that academic literacy practices were not a fixed set of skills to acquire. Rather, researchers represented disciplinary literacy practices as coconstructed and situationally defined, marking concurrent membership in multiple discourse communities. Similarly, researchers turned to discourse analysis to reveal that what counted as knowledge in particular disciplines was dynamic and affected by setting-specific social relations, texts, and discourses. This account of disciplinary knowledge and discourses promoted access and equity by working against the notion that academic literacy is a set of autonomous, decontextualized skills (see Street, 1984, 1993).

By demonstrating that disciplinary discourses and definitions of disciplinary knowledge are dynamic, while also acknowledging that power relations help determine which versions of disciplinary discourses and knowledge are valued in educational contexts, this research called on researchers, educators, and policymakers to acknowledge that disciplinary discourses function as "social languages"(Gee, 2005a). Studies made explicit the values embedded in disciplinary social languages and social definitions of knowledge, while also considering how classroom discourse communities could and should help students build a bridge between their own identities, discourses, and knowledges and those of academic disciplines.

Contending that disciplinary knowledge is not static, but socially constructed through language, interaction, and cultural practices (Hines \& Appleman, 2000), various studies applied discourse analysis to interrogate what counts as knowledge in various disciplinary or content area contexts inside and outside of school. They described ways in which teachers called upon their own authority and the authority of established disciplines to determine what kinds of knowledge were valued (Thesen, 2001). Sometimes this authority was shown to constrain definitions of what counts as disciplinary knowledge. For example, Moje (1997) used critical discourse analysis to demonstrate the ways the discourses of a high school chemistry class positioned the teacher as expert and producer of knowledge, reproducing dominant notions of what counts as science knowledge. Moje argued that researchers must attend to classroom and content area discourses (i.e., meso discourses) to consider how they are shaped by macro disciplinary discourses and the ways they reproduce or construct assumptions about what counts as disciplinary, in this case science, knowledge.
From another perspective, research also illustrated how a teacher distributed authority and expanded definitions of disciplinary knowledge. Rex and McEachen (1999) studied the negotiation of reading and writing knowledge in an accelerated English class of students with overlapping rates of achievement who were previously tracked as general and gifted and talented. Analyses of key micro discursive interactions over the first 21 days depicted how key interactional moves shaped local definitions of what counted as literate knowledge and of whose knowledge counted. Rex and McEachen argued that equitable access occurred because all students were positioned to feel their literate knowledge and identities were at risk.

One challenge taken up by discourse analysis studies of content area knowledge was to provide methodologies that acknowledged and incorporated students' many funds of knowledge and varieties and genres of discourses. For example, Crawford (2005) argued that asking students to demonstrate science knowledge in written discourse alone privileged some students while alienating others. When students were offered opportunities to use multiple modes of discourse, more were able to display their academic knowledge. After illustrating that written records of students' science literacies do not take into account the social and discursive nature of knowledge or accurately demonstrate students' disciplinary competencies, Crawford called on researchers to collect observational data that focuses on the oral discursive practices of science students.

Other scholars have urged researchers to study the strategic integration of the various knowledges and discourses that students encounter in and out of school, proposing a third space that merges multiple funds of knowledge and discourses to forward equitable disciplinary literacies (Gutiérrez, 2008; Gutiérrez, Baquedano-López, \& Turner, 1997; Moje et al., 2004).

Researchers interested in productive participation in disciplinary knowledge building also considered the ways in which discursive disciplinary practices may conflict with or complement students' personal and schooling histories. Contributions to understanding this problem have been made by a number of discourse analysis studies in science classrooms. Brown (2004) demonstrated that intrapersonal conflict can emerge for ethnic minority students who were asked to appropriate science discourse and recommended that science teachers make scientific discourse a more explicit element of their curricula. Focusing on discursive integration, Gomez (2007) suggested incorporating students' everyday science talk into classroom discourses to help instill basic scientific concepts.

A number of studies on disciplinary literacies linked to students' discourses incorporated a sociocultural perspective as well as ethnographic approaches 
and sociolinguistic discourse analysis. These researchers attempted to make explicit the ways in which each classroom's set of cultural practices were interactionally constructed-via discourse-by the teacher, students, texts, and assumptions about disciplinary knowledge and discourses (e.g., Rex, 2001).

Reveles, Cordova, and Kelly (2004) used a sociocultural perspective to argue that when students identify as scientifically literate members of their classroom community, they are able to maintain their identity affiliations while also developing academic identities. They argued that discursive identity must be used as an analytical tool to illuminate the affiliation and alienation associated with the appropriation of disciplinary discourses. They contended that students' abilities to become part of an academic or classroom discourse community may depend on how they are allowed to position themselves in relation to the subject matter, discourse practices, and membership in the community (Brown, Reveles, \& Kelly, 2005). Still other researchers distinguished between scientific discourses and pedagogical discourses and claimed that science teachers can make science discourses accessible to all students by adopting a hybrid discourse of science talk and other pedagogical discourses (Hanrahan, 2006).

Research on disciplinary discourses, identities, and knowledge also includes a significant body of scholarship on the interpersonal dimensions of professionally written academic texts, including research studies. Hyland (2005) reviewed 240 published research articles from eight disciplines and insider informant interviews to analyze the linguistic resources of intersubjective positioning. Hyland's analyses illustrated how the discoursal preferences of disciplinary communities construct writers and readers alike.

Research such as Hyland's (2005) illustrated that texts representing disciplinary knowledge in the academy construct and negotiate social relations within particular discourse communities. Studies such as this build upon scholarship by Bazerman (Bazerman $\&$ Prior, 2003) that construed written academic texts as situated and social, thus allowing insights on how the literate practices of the academy are implicated in representations of disciplinary literacies in schooling. Such scholarship complicates the contributions of studies of academic literacy practices within schools (Lillis, 2001). Nevertheless, researchers concluded that English-language learners, in particular, could benefit from a sociolinguistic examination of the disciplinary discourses in academic writing (Leung $\&$ Safford, 2005; Schleppegrell, 2004). Boughey (2000) for example, argued that in South Africa, the difficulties that nontraditional students experienced stemmed from their lack of access to academic literacy discourse, rather than from ESL issues.
Researchers who focused on school-based, studentwritten academic texts and the sites in which they were produced asserted that discourses about disciplinary literacies were also multiple, connected to power relations, and sometimes in competition. Ivanič (2004) described six of these distinct discourses that comprised writing pedagogy. Lea and Street (2006) proposed that educators rely on three models: the skills model, an academic socialization model, and an academic literacies model when teaching writing. They argued that not only must students appropriate the discursive practices of a particular discipline and discourse community, they must also negotiate sometimes competing models of literacy learning.

Research making use of discourse analysis to explore disciplinary literacies promoted access and equity by challenging stereotypical assumptions about disciplinary knowledge as discrete, stable, and fixed. Content knowledge was explored and displayed as discursively built within social relations, discursively produced as textual renderings, and pedagogically influenced through discursive moves. Learners and producers of disciplinary content were represented as occupying discursive stances and engaged in discursive negotiations. Whether in classrooms or in academic texts, researchers looked for relationships among the literate positions of knowledge producers and discursive practices and consequences. Those consequences illustrated what became authorized as disciplinary knowledge and how, who could or chose to participate, and who or what was served.

\section{How Can Schools Provide Students With Access to School-Based Literacies?}

Discourse analytical studies have been used to illustrate how schools (and the teachers and processes within them) can create access opportunities for students whose identities and literacy practices have been historically marginalized. This purpose is addressed by using discourse analysis to focus on both the discursive interactional and text-based practices in and out of school sites and their relevance to literacy learning access. Also to a degree comparable to other categories, these researchers pointed to equitable access by understanding issues of agency and authority of persons, practices, and genres, which involved viewing literacies as sociocultural practices, locally negotiated but situated in relation to macro ideologies and power structures. The studies in this section are organized to focus on their contributions to understanding how to access schoolbased literacies through classroom participation struc- 
tures, revised definitions of literacy, and an expanded notion of what counts as school-based literacies.

Researchers who focus on classroom participation through discourse analysis have directed their studies to concerns about the legitimacy of various forms of nonschool literacies for academic purposes. They have argued that teachers can provide access to legitimate, school-based literacy by validating literate resources students bring to class (Larson \& Irvine, 1999; Maloch, 2005a, 2005b) and students' voices (Phelps \& Weaver, 1999). To understand how such validation could work, Maloch (2005a, 2005b) applied Mercer's (1995) guided construction of knowledge concept to view interactional reading practices in a second-grade classroom.

Analyzing the teacher's use of guided participation, Maloch (2005a, 2005b) noted how the teacher "drew students' attention again and again to a shared frame, or context, for reading that valued authentic, enjoyable, and active encounters with text...as she guided them in their appropriation of reading skills and strategies" (Maloch, 2005a, p. 16). Maloch concluded that the shared frame of reading students continually constructed together was a critical contextual resource for their learning. Through her illustrative interactional analysis she argued for the importance of threading connections across lessons, to and from the developing shared frame for reading students' personal lives. Metalanguage was displayed as central for students in building a cohesive framework about reading in which skills, strategies, and the mechanics of reading were exercised within a context of authentic purposes for reading.

Other discourse analysis research interested in teacher-student discursive interaction has explored how teachers' participation guidance practices can constrain, rather than support, students' access to learning (Larson $\&$ Irvine, 1999). As in Maloch's research, Larson and Irvine's discourse analytical methodology generated a theoretical language for educators to understand the complications of their discursive practices. They conceptualized "reciprocal distancing" as the discursive process of face-to-face classroom interactions in which teachers and students reproduced societal sociocultural distances. Through sociohistorical (in relation to sociocultural) perspectives, the researchers emphasized the importance for practice of validating students' sociocultural and linguistic resources, in this case African American Vernacular English. They built upon research by Michaels (1981) that pointed to teachers' discourse practices as pivotal in maximizing or minimizing joint production of literacy knowledge.

Other recommendations derived from discourse analysis studies as to how schools can provide historically marginalized students with access to school-based literacy learning include expanding and reframing definitions of literacy to understand the reading of social relations as social texts (Majors, 2007), to include academic (i.e., essay) writing as interactional (Lee, 2008), to entertain multiple literacies (Carter, 2006), and to move readers from one framework for reading to another (McDonald, 2004). For example, in her analysis of a fifth-grade class reading of a literary text, McDonald argued for a response analytic continuum through which students could be encouraged to move from a reader response theory approach to more critical readings. Her study comparatively analyzed transcripts of critical and noncritical classroom readings to illustrate how the teacher engaged students to bridge lived reality/ cultural knowledge with critical stances. McDonald argued for a developmental continuum of ways of reading that allow students to assume critical positions through which "they position themselves within an alternative discourse of reading, participating in a critical literacy" (p. 18).

Some discourse analysis research explores literacy practices in community contexts students and their families inhabit outside of school as a means to theorize productive school practices for accomplishing academic literacy learning. In her ethnographic study of "shoptalk," a meso discourse unique to African American hair salons, Majors (2007) challenged dominant conceptions of texts, literacy, and literate contexts, by illustrating how literacy skills acquisition and use permeated various contexts. Redefining literacy in terms of the reading of social relations as socially constructed texts, she contended that by cultivating African American students' sophisticated skills of reading social relations and problem solving in community-based contexts, teachers in her study could have guided their access to schoolbased literacy skills.

Using other frames, researchers have noted the resilience of students in learning school-based literacies that conflict with their own. Carter (2006) illustrated how in the absence of teacher-provided opportunities, two African American 12th graders in a predominantly white English classroom gained access to literary literacies. With selectively transcribed and analyzed transcripts, she represented how, by assuming insightful stances about the competition between identity and knowledge playing out in their traditional Eurocentric classroom, the young women were successfully strategic. Using nonverbal communication, they created culturally affirming classroom spaces to legitimize their own literacy practices and identities.

In her microethnographic discourse analysis of language and literacy events, Carter (2006) took a multiple literacies approach to study classroom discourse as a negotiation through which ways of knowing and language and literacy practices are valued. She conceptualized multiple literacies 
as the social and cultural ways in which students communicate in their everyday lives as they engage, analyze, and critique the world around them... [which are] part of an interpretive framework that informs how they engage in language and literacy events and understand texts (p. 353).

Carter asserted that teachers of students of color should use a multiple literacies approach to interrogate power relations and validate students' social and cultural interpretive frames. By extension, she and other researchers who have used a multiple literacies frame (e.g., Haneda, 2006; Paul \& Wang, 2006; Perry, 2006) argued that it holds the potential to challenge traditional conceptions of literacy at the macro level, conceptions that have resulted in labeling students as "powerless, failing, struggling, and/or having low literacy abilities" (Carter, 2006, p. 354, emphasis in original).

Hicks (2005) and Luna (2003) joined these researchers in endeavoring to contest and productively complicate the binary "powerless versus the powerful" macro discourse in literacy studies. This move to acknowledge and complicate structural power theories-such as insider-outsider, central-marginal, enfranchiseddisenfranchised, active-passive-inherited from sociological theories of education appeared frequently among the reviewed studies. In Hicks's and Luna's case, their studies were situated in contexts outside of the classroom: in an after-school reading program for workingclass girls (Hicks, 2005) and in a student action group for undergraduate students labeled as learning disabled (LD) (Luna, 2003). The discourses they analyzed represented meso discourses pertinent to those specific social settings. Focused specifically on social class distinctions, Hicks illuminated how critical pedagogy that validated students' lived experiences could reposition working-class girls in relation to school-based literacies. Also adopting the view that literacy is situated in everyday social life, Hicks used discourse analysis to argue for the girls' potential to become "bilingual," blending their working-class voices with middle class voices that characterized schooling, if productive hybrid spaces (Gutiérrez et al., 1997) were afforded by teachers.

Luna (2003) focused on students categorized by schools as LD to explore how critical literacies could reposition students labeled LD in relation to dominant macro discourses. She illustrated how students drew from their collective experiences as LD-labeled students to critique the dominant discourses of schooling and the LD field. Luna's analysis conveyed how students generated an alternative discourse based on a more positive construction of their literacy and learning abilities and repositioned themselves as authorities on alternative learning in relation to the university and its discourses. The question of agency within powerful schooling policies, procedures, and practices repeatedly asserts itself in these studies: Whether students could be agentive, and if so, to what extent and in what ways that worked for and against their literacy learning? (cf. Rex, 2006b)

These studies raised the question of where (if at all) to draw the line in determining which literacies should be legitimized in school. Depictions of micro (Carter, 2006) and meso (Majors, 2007) discourses that challenged macro discourses, and of micro discourses that should be challenged (Larson \& Irvine, 1999), were complemented by arguments that alternative literacy practices could not only serve as a bridge to schoolbased literacies, but also represent goals to work toward as legitimate school-based literacies (Hicks, 2005; Luna, 2003). Luna's and Hicks's explicit stance for the legitimization of alternative literacies in schools was complemented by other research that favored expanding definitions of literacy and repositioning marginalized students more favorably in relation to current dominant discourses of literacy and schooling.

\section{What Are the Shifting Roles of Literacy Teachers and Learners Within and Outside of School?}

The application of discourse analysis to literacy practices in the reviewed studies worked against reductive tendencies observed in macro discourses to cast teachers and students as effective or ineffective, able or incompetent. Teachers and students were perceived as occupying changeable roles constituted in and through their discursive practices in relation to the discursive norms of their classrooms (e.g., Roberts \& Sarangi, 2001).

Researchers interested in these shifting roles often investigated situations where students and teachers took up a variety of roles both within and outside of school. They examined, for example, contexts in which teachers struggled to decentralize classroom power and students worked to accept responsibility for their own learning. Discursive theorization and analysis of the roles of "teacher" and "student" were key in these studies, making possible assertions that notions of the teacher as the sole authority and students as mere recipients of the teacher's expertise grossly underestimated the complexity of literacy learning situations both inside and outside the academic classroom.

The most common focus of research in this section was attention to the roles discursive practices allowed teachers and students to adopt during in-class lessons, meetings and discussions. Concerned with how those roles influenced cooperation among students and student meaning making, researchers conducted finegrained analyses of teacher-student interactions. One of many approaches to fine-grained study of the discursive practices of successful teachers in diverse classrooms was Knoeller's (Knoeller \& Freedman, 1998). Knoeller 
applied Bakhtin's theory (Bakhtin, 1986) of "voicing" in relation to the roles played in literature discussions led by students in an academically and ethnically diverse AP high school English class. Noting the yearlong evolution of a teachers' discursive positioning during student-led discussions of provocative texts, Knoeller concluded that during student-led discussions teachers could "witness the collaborative dynamics of textual interpretation and, perhaps, gain insight into the nature of how students position themselves in relation to the voices of others, including authors, characters and, just as importantly, classmates" (p. 227).

In a study by Mariage (2000), a fine-grained interactional sociolinguistic investigation was embedded in a two-year ethnography of the literate practice of the 'sharing chair' in a classroom with students designated learning disabled-emotionally impaired. Mariage followed sharing chair interactions to observe their impact on student roles as literate participants. Each day volunteers sat in the chair and read from their dialogue journal entries. Students assumed the roles of author or audience member with rights, duties, and responsibilities unique to each role. Mariage illustrated how, by differentially positioning students as authors, the discourse practices required ordinarily reluctant students to engage in different literate behaviors and conversational strategies such as telling stories, actively listening, questioning, and building intertextual links with others. The study contributed to claims that when literacy events create conditions that give children who are commonly considered deficient access and ownership of their learning it can lead to increases in achievement students.

Other researchers investigated how rapidly shifting teacher and student discursive roles within the classroom affected student communication and student participation. Christoph and Nystrand (2001) analyzed the roles of low-achieving inner city ninth-grade English students and their teacher during class discussions. Combining grounded theory and conversation analysis, they concluded that dialogic discourse between class participants was possible when teachers were skilled at establishing links between academic goals and students' own goals, and that dialogue seemed to catch fire when the teacher took a less controlling role and students drew upon their social relationships.

Still another way of studying shifting roles inside the classroom has been to analyze how those role shifts altered power dynamics. Orellana (1996) used critical discourse analysis to examine "problem-posing meetings," part of a teacher's critical pedagogy approach, to see how students used discursive structures to demonstrate manifestations of power. Orellana concluded that the "classroom meetings offer a potent space for the development and display of discursive power which goes far beyond traditional classroom practices and profoundly shifts traditional relationships of school authority" (p. 360).

Berry and Englert (2005) illustrated the importance of shifting power from teacher- to student-selected topics to drive and sustain conversation book discussions among inner city elementary school students with and without disabilities. Berry and Englert represented the teacher's role as crucial in apprenticing the students into what was for them a novel participation structure, which allowed many students with disabilities to assume positions of power and authority in relation to their classmates, as has been argued elsewhere (e.g., Rex, 2000).

Berry and Englert's (2005) research represents those studies that were concerned with a reciprocal model of classroom conversation and with the teacher's role in managing the conversation so as to increase cognitive abilities. "The teacher does not remain in the position of ultimate 'cognitive authority,' but gradually shifts responsibility to students for employing interpretive strategies, as well as for asking questions, clarifying meanings, and justifying and evaluating answers" (p. 36).

Researchers also studied the discourses that teachers at many stages of their careers use to position themselves into authoritative roles within classrooms (both knowingly and unwittingly) so as to take on the role of "teacher." Assaf (2005) studied the multiple discourses a preservice teacher deployed in a reading specialization program to make sense of her learning in the program: immigrant, multilanguage learner, and writer/poeteach of which affected both her sense of self as a teacher and how her peers recognized her. Assaf contended that negotiating multiple discourses also influenced the teacher's instructional decisions.

Juzwik (2006) was concerned with how teachers new to the classroom negotiate an authoritative identity with their students. By pairing conceptualizations of narrative performance and authority, or ethos (the rhetorical invention of one's identity for persuasive purposes), Juzwik examined how a beginning teacher narratively positioned herself and her middle school students during a six-week Holocaust unit. Juzwik argued for the contributions a rhetorical perspective can make to educational research in that "narratives in teaching can be seen as an art of deploying rhetorical resources for persuasive purposes in classroom contexts" (p. 495).

Some researchers have studied discourse to address shifting roles of teachers and learners involved in literacy situations outside of the classroom. As has been the case in other research we have reviewed, researchers with this focus analyzed positive and negative cases to test frameworks and directions for applied research 
and also to reveal and contest conditions sustaining inequitable access.

Heffernan and Lewison (2005) studied a positive case in which third-grade students acted upon the critical literacy they had been studying in their classroom while reading and talking about social issues such as racism, ageism, and sexism. Drawing on three different conceptions of critical literacy the researchers examined how students successfully "desegregated the lunchroom" and "became border crossers, bringing together the Discourse of the classroom with the Discourse of the lunchroom" (p. 108).

Dawes (2007) used discourse analysis to scrutinize interactions between corporate volunteers and children at a read-aloud program because "Previous studies of the read-aloud event have tended to isolate the participants, focusing on adult behaviors or on child behaviors, without considering how the adult and child interact or the role text plays in their interactions" (p. 10). By analyzing the read aloud events, Dawes found that throughout the partnerships the discussions, texts, and activities worked "to shape larger meanings about adults, children, literacy, and learning" (p. 17).

In a university setting, Thonus's (1999) examination of interactions during 16 tutorial sessions described the discursive qualities of tutor dominance and found that these features remained relatively constant in interactions with male and female tutees or with native and nonnative speakers of English. Her analysis was meant to interrogate the features of institutional discourse, and she argued that the results of her analysis suggested institutional context outweighed gender and language proficiency in defining participant roles and in sanctioning tutor dominance behaviors.

Attention to how the roles of literacy stakeholders were constituted and shifted has highlighted relationships among micro interactions, meso discursive genres and macro discourses to illuminate authoritative identities and practices. These contributions have reframed literacy-related issues, argued for particular literacyrelated practices and challenged literacy education to complicate how the role "teacher" and "student" is conceptualized and enacted.

\section{How Does Discourse Analysis Research Address Movement Within and Across Literacy Sites and Practices in a Globalized and Digital World?}

Research in this section addresses literacy sites, both physical and virtual, and literacy practices that were viewed as emerging or being defined in the 21 st century (Kahn \& Kellner, 2005; Kress, 2003; Kress $\&$ Van Leeuwen, 2001). A main concern for those exploring the complex relationship between new technologies and multimodality (often referred to as "New Literacies") was the perception of an ever-widening gap between those who are positioned to have access and those who are not.

Aarsand (2007) studied gaps in intergenerational digital literacy by observing family members engaged in video and computer game activities. Applying discursive psychology to ethnographically collected data, he described how members of a family constructed roles for themselves as more or less able digital participants, within a digital divide narrative, which established positions of power as to who could use which digital literacy resources, when, and how. Aarsand's analysis cast the macro generational digital literacy divide as a result of joint micro actions that positioned children as digital literates, concluding that the digital divide has to be related to activities in situ that involve the handling of software and hardware. Aarsand asserted that

what has been called the digital divide is not a problem that can be merely related to a predefined generation. Rather, it seems to be a resource invoked for different purposes in social interaction, depending on time, place and activity. (p. 252)

Discourse analysis studies of multimodality as language processing across traditional modes of spoken and written texts provide ways to understand comparable qualities, (such as information density), in language genres (for instance narratives), in separate languages (including English and Hebrew) (Ravid \& Berman, 2006). Those studies contribute to more fully understanding the affordances and demands that spoken and written language may put on second-language learners in classrooms (Poole, 2003).

However, Bourne and Jewitt (2003), in their research on literate classroom interaction as multimodal, argued that "speech and writing are just two modes among many" (p. 65). In her review of research into multimodality and literacy in classrooms, Jewitt (2008) offered two framing arguments as key to literacy phenomenon: "that it is not possible to think about literacy solely as a linguistic accomplishment and that the time for the habitual conjunction of language, print literacy, and learning is over" (p. 241).

Claims for the importance of multimodality in studying literacy are part of a vigorous debate among state and corporate stakeholders, academic disciplinary factions, cultural interests, and social organizations, ranging from the local to the global. Although the focus, constitution, and benefits of literacy have always been contested, globalization and the Internet have accelerated that debate so as to focus on the nature and benefits of what Kahn and Kellner (2005) called technoliteracy. 
For their part, Kahn and Kellner drew upon the language of multiple literacies (Lonsdale \& McCurry, 2004) to argue for a critical theory of technoliteracies.

Literacy researchers using discourse analysis have engaged this debate by arguing for the direction of research inside, outside, and beyond the classroom (C. Luke, 2003) and by purposefully engaging and also challenging definitions of new literacy(ies). Jacobs (2004) tested a methodology involving synchronous discourse analysis of a subject both online and offline to examine young people's ability to multitask when using interactive technology, such as instant messaging. From a New Literacy Studies perspective (cf. Gee, 2000d; Street, 1993) ${ }^{2}$, in an initial study exploring how a young girl interacted both in physical and virtual spaces simultaneously, Jacobs hoped "to see whether and how participants create and cross boundaries and carry online literacy practices into their offline worlds and vice versa" (p. 399).

In a follow-up article on the same study, Jacobs (2006) further examined how multitasking youth were being prepared to become "shape-shifting portfolio persons" (a concept from Gee, 2000c), who can play the roles of "consumer, producer, and distributor" (p. 171) by building collaborative and interactive abilities as well as collecting, assembling, and distributing skills required by fast capitalism. Jacobs concluded that activities like instant messaging may provide young people with more options for economic success within a fast capitalist, information-based economy than it might people who lack access to the practices and roles afforded by a digital literacy such as instant messaging.

Extending the benefits/constraints line of argument about new literacies inside and outside of school, Maybin (2007) challenged New Literacy Studies' reliance on "the home/school mismatch hypothesis," the basis of much literacy research over the last twenty years (p. 516). She designed her study "to contribute to a re-examination of what counts as 'school literacy' and 'classroom talk', by building understanding on an analysis of empirical data which does not assume the powerful home/school or vernacular/schooled dichotomous framings" (p. 516). In her ethnographically informed discourse analysis study of two classrooms of white working class $10-11$ year olds, Maybin illustrated that official literacy activities were not necessarily 'schooled' and unofficial activities were not completely 'vernacular.' She presented relationships between children's activities and the literacy practices connected with schooling and other institutional domains as "hybrid multimodal literacies" (pp. 524-527).

Researchers have been redefining how to understand literacy education beyond thinking of it as inside or outside of the classroom. For example, Britsch (2005) explored the impact of physical divide by having a class of third graders and adults communicate about academic subjects via e-mail across 2,000 miles. She discovered complications in the concept of thirdspace-electronical and spatial-as conceptualized in the classroom by Gutiérrez et al. (1997) and concluded that "[b]ecause the thirdspace is a negotiated one, the nature of the writing in such an environment cannot be mandated" (p. 352). Britsch's description of the time/space/media engagements over one year led her to suggest a redefinition of "learning that would derive from and reflect a mega-context including not only 'factual reality' but also originative reality where currently inscribed curricular and personal knowledges stimulate new, more 'immersive' (Bendito, 2004: 61) multi-textual experiences" (p. 128).

Several studies warned of the negative consequences researchers and instructors face should they ignore the impact of these third spaces and varied spaces, including the idea that students may be prevented from learning when experiencing dissonance in text production (Dowdall, 2006), or that online users with more experience and skill in multimodal literacies and virtual spaces may use them to gain rhetorical advantage when communicating with others (Potter, 2004).

Concerns about inequitable advantage resulting from globalization and commercialization of education beyond official schooling was the focus of research by Buckingham and Scanlon (2001), who provided a rhetorical analysis of "edutainment" magazines aimed at preschool children, whose parents harbor educational aspirations. Analyzing mode of address and positioning of the child reader, Buckingham and Scanlon noted how the magazine took an integrated marketing approach characterized by "trans-media intertextuality" (Kinder, 1991) that included television programs, films, records, books, comics and magazines, computer games and toys, T-shirts, posters, lunchboxes, drinks, sticker albums, food and a myriad of other products." Buckingham and Scanlon's analysis illustrated that although education is being sold to parents and young children, the methods and means are powerful sources of identity formation for the learner and the parent as well as messages about learning.

Acknowledgment of widespread global multilingualism in nation states and the challenges posed to literacy policymakers has also been framed as an equitable access issue. Offering his own situation-"as a researcher and bureaucrat trying to come to grips with the unreconciled issue of redistributive social justice in Australian education: the educational achievement and life pathways of Aborigine and Torres Strait Islander children and youth" (A. Luke, 2003, p. 133)—as a case study, Luke analyzed the discourses that have historically informed literacy education research and policy for these constituents. He asserted that existing discourses 
of multiculturalism and compensatory education were no longer adequate to achieve "proper evidence-based policy formation" (p. 133) to deal with the social and demographic impacts of postcolonialism and economic globalization, where culturally and linguistically diverse student bodies have become the norm.

A. Luke (2003) defined the challenge as one of providing literacy education of value and use for learners in circumstances in which "the available discourses, background knowledges, repertoires of practices and motivation structures for learning and using literacy... are as contingent on those extra-educational social relations and linguistic markets that they inhabit before, during, and after schooling" (p. 137). He called on researchers concerned with multilingual communities to pursue research questions that could inform language and literacyin-education policy, all of which can be pursued with discourse analytic approaches.

Consonant with Luke's call, Lewis and Fabos (2005) studied students' taken-for-granted use of the instant messaging multiliteracy and their parents' and teachers' lack of familiarity and distrust of these literate practices. Lewis and Fabos sought to understand the functions instant messaging served in students' lives: For what purposes did they use this form of digital literacy? For what reasons and under what circumstances did they find it most compelling? A number of other researchers have taken an interest in compared literacy skills deemed improper in schools across the globe, yet commonplace in homes and communities, and how those who engage with them are perceived. Kramer-Dahl (2004) studied Singaporean youth taking up multiple reading strategies and positions in extracurricular negotiations with texts to challenge cultural stereotypes about such practices and the young people who engage in them.

Students whose first language is not the language of schooling have also been the focus of many researchers who have studied new media literacies, schooling, and identity. For example, in the United States, Lam's (2006) study of Chinese immigrants who, while learning English, contrasted their locally positioned identities with those they could assume when online, illustrated how in transnational virtual spaces the young Chinese created new multilingual, multiliterate learning experiences, competences, and representations of linguistic and cultural identities that contrasted with predominantly monolingual, monocultural, and nation-centric views of the adaptation and educational trajectory of immigrant students (see also Lam, 2009).

Discursive constructs and methods of analysis have also led researchers to warn against romanticized constructions of multiliteracy engagement in new media. Soep (2006), in studying artifacts of an after-school youth media program, noted undesirable discourses in these media. She reported the presence of Bakhtin's
(1981) "double voiced discourse" (Soep, 2006, p. 202) stereotypes and Tannen's (1989) "dramatized confrontation" (Soep, 2006, p. 204) in young filmmakers' peercritiques. Soep argued that if literacy educators continue to view new media as a site for not only acquiring multiliteracy, but also for "considering implicit messages, assumptions, and biases within their own and others' products, and to understand the social structures and tensions behind systems of media production and consumption" (p. 208), then they should look closely at the moment-to-moment creation of media literacy to see the discourses in use.

Researchers have also continued to study the tangible role that social spaces and activities play in studying increasingly mobile populations and their literacy practices. Aukrust (2004) examined 5-year-old Turkish children's explanatory talk in Norwegian playgrounds and classrooms to illuminate the affordance that peer play offered in second-language acquisition when students engaged with multilingual classmates. Other studies examined how literacies were undervalued in the classroom, such as the sometimes underappreciated learning, literacy, and life experiences that adult learners bring with them to adult education programs (Rogers, Tyson, \& Marshall, 2000), or the negative view about Spanish speakers that Hispanic or Latino children were cultivating because of official English laws in the United States (Martínez-Roldán \& Malavé, 2004).

However, though researchers continue to pursue established research perspectives and frameworks, increasingly discourse analysis is being put to new, exploratory uses-analyzing new forms and modes of literacies in relation and comparison to previous, more established modes of literacy. The problem of literacy education in the 21st century is being purposefully taken up by a substantial cadre of discourse analysis researchers who are studying relocation, commercialization, and new digitization, often in combination. New theorizations to create new frameworks for research that explores and contests the emerging research is appearing. The diversity of such exploration-from studying how Massively Multiplayer Online Games (MMOGaming) can inform communication in online learning (Steinkuehler, 2006) to how second-language learners can form identity and language skills by supplementing their classroom instruction with online interactions (Lam, 2000)_-seems to have taken hold.

\section{Summary and Final Comments}

Discourse analysis studies of literacy and education (as we have defined them here) were explicitly or implicitly oriented to understanding how the literacy education of all students could be successfully accomplished, in light 
of the historic inequities that have prevented achievement of that goal. Located in a variety of fields and subspecialties (e.g., literacy, English education, linguistic anthropology, early childhood education; cultural studies, reading, linguistics, composition, ethnomethodology, discursive psychology, and sociolinguistics), researchers have taken up various methods of discourse analysis (e.g., narrative analysis, critical discourse analysis, critical discourse analysis, positioning analysis, genre analysis, interactional sociolinguistic analysis, microethnographic analysis, and their adaptations).

The versions of literacies, literacy processes, and identities researchers created through these studies' discursive lenses meant for some focusing on the structure of discourse; for others its functionality; for others its social role; and for some others its communicative features in terms of context and cultural interaction, with many of the studies combining these foci. This robust texture of perspectives, frameworks, methodologies and methods refined, exploded and redefined the location and nature of what can be viewed as "the problem," addressing it over the last decade in five dimensions:

1. How literate identities are constituted and constructed, and by whom

2. How disciplinary knowledges, discourses, and identities are constructed

3. How schools can provide students with access to school-based literacies

4. The shifting roles of literacy teachers and learners within and outside of school

5. Movement within and across literacy sites and practices in a contemporary, globalized, and increasingly digitally influenced world

Given the liquidity of literacies and literate practices and their interrelated multiplicity, as well as the shapeshifting of literate identities, it seems safe to assume that these dimensions as a footprint of discourse analytical literacy research will also change. So, too, will the forms of discourse analysis designed to meet them (cf. McHoul $\&$ Luke, 1989). Which is to note that in complex ways the nature of the object of study (people's engagement in literacy and education) and the nature of discourse analytic studies are dialectically constitutive.

\section{Notes}

${ }^{1}$ The transcription applies a few notation conventions common among discourse analysts of interaction.

\begin{tabular}{|l|l|}
\hline[ & Talking simultaneously \\
\hline$(.2)$ & Pause time in seconds (e.g., 2 seconds pause) \\
\hline$=$ & Talking immediately as speaker finishes \\
\hline- & $\begin{array}{l}\text { Underlining reflects emphasis through louder volume or } \\
\text { stress }\end{array}$ \\
\hline
\end{tabular}

${ }^{2}$ Although similarly phrased, the New Literacy Studies and the New Literacies are distinct concepts. The first refers to a perspective on the study of literacy closely associated with the social turn in literacy research and what has been labeled an ideological model (cf., Street, 1984); the latter is associated with the use of digital technologies and not necessarily any particular perspective or model of literacy(ies).

The authors thank editors David Bloome and Ian Wilkinson as well as reviewers Janet Maybin and Stephanie Carter for their invaluable recommendations and comments on an earlier draft.

\section{References}

Aarsand, P.A. (2007). Computer and video games in family life: The digital divide as a resource in intergenerational interactions. Childhood: A Global Journal of Child Research, 14(2), 235-256.

Altbach, P.G. (2005). Globalization and the university: Realities in an unequal world. In J.J.F. Forest \& P.G. Altbach (Eds.), International handbook of higher education (pp. 121-140). New York: Springer.

Alvermann, D.E., Young, J.P., Green, C., \& Wisenbaker, J.M. (1999). Adolescents' perceptions and negotiations of literacy practices in after-school read and talk clubs. American Educational Research Journal, 36(2), 221-264.

Assaf, L.C. (2005). Exploring identities in a reading specialization program. Journal of Literacy Research, 37(2), 201-236. doi:10.1207/ s15548430jlr3702_4

Aukrust, V.G. (2004). Explanatory discourse in young second language learners' peer play. Discourse Studies, 6(3), 393-412. doi:10.1177/1461445604044296

Bakhtin, M. (1981). Discourse in the novel. In M. Bakhtin, The dialogic imagination: Four essays (M. Holquist, Ed.; C. Emerson \& M. Holquist, Trans.; pp. 259-422). Austin: University of Texas Press.

Bakhtin, M.M. (1986). Speech genres and other late essays. Austin: University of Texas Press.

Bauman, Z. (2000). Liquid modernity. Cambridge, MA: Polity.

Bausch, L.S. (2007). Boy-talk around texts: Considering how a third grade boy transforms the shape of literacy in book talk discussions. Journal of Early Childhood Literacy, 7(2), 199-218. doi:10.1177/1468798407079287

Bazerman, C., \& Prior, J. (2003). What writing does and how it does it: An introduction to analyzing texts and textual practices. Mahwah, NJ: Erlbaum.

Bendito, P., (2004). Metaphors and meta-experience in technology side effects: A multimedia exhibit. In R. E. Griffin, J. Lee, \& V. S. Chandler (Eds.), Changing tides: selected reading (pp. 55-62). Loretto, PA: International Visual Literacy Association.

Berry, R.A.W., \& Englert, C.S. (2005). Designing conversation: Book discussions in a primary inclusion classroom. Learning Disability Quarterly, 28(1), 35-58. doi:10.2307/4126972

Blommaert, J. (2005). Discourse. Cambridge: Press Syndicate of the University of Cambridge.

Blommaert, J., Muyllaert, N., Huysmans, M., \& Dyers, C. (2005). Peripheral normativity: Literacy and the production of locality in a South African township school. Linguistics and Education: An International Research Journal, 16(4), 378-403.

Bloome, D. (1985). Reading as a social process. Language Arts, 62(2), 134-142.

Bloome, D., Carter, S., Christian, B., Madrid, S., Otto, S., ShuartFaris, N., et al. (2009). On discourse analysis in classrooms: Approaches to language and literacy research. New York: Teachers College Press.

Bloome, D., Carter, S., Christian, B., Otto, S., \& Shuart-Faris, N. (2005). Discourse analysis and the study of classroom language and literacy events: A microethnographic approach. Mahwah, NJ: Erlbaum. 
Bloome, D., \& Clark, C. (2006). Discourse-in-use. In J. Green, G. Camilli, \& P. Elmore (Eds.), Complementary methods in research in education (3rd ed., 227-244). Mahwah, NJ: Erlbaum.

Blunt, A. (2004). Literacy discourse analysis: Making space at the policy table. Adult Basic Education: An Interdisciplinary Journal for Adult Literacy Educational Planning, 14(1), 3-17.

Boughey, C. (2000). Multiple metaphors in an understanding of academic literacy. Teachers and Teaching: Theory and Practice, 6(3), 279-290.

Bourne, J., \& Jewitt, C. (2003). Orchestrating debate: A multimodal analysis of classroom interaction. Reading: Literacy and Language, 37(2), 64-72.

Britsch, S.J. (2005). "But what did they learn?" Clearing third spaces in virtual dialogues with children. Journal of Early Childhood Literacy, 5(2), 99-130. doi:10.1177/1468798405054581

Brown, B.A. (2004). Discursive identity: Assimilation into the culture of science and its implications for minority students. Journal of Research in Science Teaching, 41(8), 810-834. doi:10.1002/ tea. 20228

Brown, B.A., Reveles, J.M., \& Kelly, G.J. (2005). Scientific literacy and discursive identity: A theoretical framework for understanding science learning. Science Education, 89(5), 779-802. doi:10.1002/sce.20069

Brown, J.S., Collins, A., \& Duguid, P. (1989). Situated cognition and the culture of learning. Educational Researcher, 18(1), 32-42.

Buckingham, D., \& Scanlon, M. (2001). Parental pedagogies: An analysis of British 'edutainment' magazines for young children. Journal of Early Childhood Literacy, 1(3), 281-299. doi:10.1177/14687984010013003

Cairney, T., \& Ashton, J. (2002). Three families, multiple discourses: Parental roles, constructions of literacy and diversity of pedagogic practice. Linguistics and Education, 13(3), 303-345. doi:10.1016/ S0898-5898(02)00089-X

Carrington, V. (2005). Txting: The end of civilization (again)? Cambridge Journal of Education, 35(2), 161-175. doi:10.1080/03057640500146799

Carspecken, P. (1996). Critical ethnography in educational research: A theoretical and practical guide. New York: Routledge.

Carter, S.P. (2006). "She would've still made that face expression": The uses of multiple literacies by two African American young women. Theory Into Practice, 45(4), 352-358. doi:10.1207/ s15430421tip4504_9

Cazden, C. (2001). Classroom discourse: The language of teaching $\&$ learning (2nd ed.). Portsmouth, NH: Heinemann.

Christie, F., \& Martin, J.R. (2005). Genre and institutions: Social processes in the workplace and school. New York: Continuum.

Christoph, J.N., \& Nystrand, M. (2001). Taking risks, negotiating relationships: One teacher's transition toward a dialogic classroom. Research in the Teaching of English, 36(2), 249-286.

Clarke, L.W. (2007). Discussing Shiloh: A conversation beyond the book. Journal of Adolescent \& Adult Literacy, 51(2), 112-122. doi:10.1598/JAAL.51.2.3

Crawford, T. (2005). What counts as knowing: Constructing a communicative repertoire for student demonstration of knowledge in science. Journal of Research in Science Teaching, 42(2), 139-165. doi:10.1002/tea.20047

Dagenais, D., Day, E., \& Toohey, K. (2006). A multilingual child's literacy practices and contrasting identities in the figured worlds of French immersion classrooms. International Journal of Bilingual Education and Bilingualism, 9(2), 205-218.

Dawes, E.T. (2007). Constructing reading: Building conceptions of literacy in a volunteer read-aloud program. Language Arts, 85(1), $10-19$.

Devitt, A. (1993). Generalizing about genre: New conceptions of an old concept. College Composition and Communication, 44(4), 573 586. doi:10.2307/358391
Dowdall, C. (2006). Dissonance between the digitally created words of school and home. Literacy, 40(3), 153-163. doi:10.1111/j.14679345.2006.00421.x

Dworin, J.E., \& Bomer, R. (2008). What we all (supposedly) know about the poor: A critical discourse analysis of Ruby Payne's "Framework." English Education, 40(2), 101-121.

Edelsky, C., Smith, K., \& Wolfe, P. (2002). A discourse on academic discourse. Linguistics and Education, 13(1), 1-38. doi:10.1016/ S0898-5898(01)00065-1

Edwards, D., \& Mercer, N. (1987). Common knowledge: The development of understanding in the classroom. New York: Falmer.

Edwards, D., \& Mercer, N. (1989). Reconstructing context: The conventionalization of classroom knowledge. Discourse Processes, 12(1), 91-104.

Edwards, D., \& Potts, A. (2008). What is literacy? Thirty years of Australian literacy debates (1975-2005). Paedagogica Historica, 44(1-2), 123-135. doi:10.1080/00309230701865496

Egan-Robertson, A. (1998). Learning about culture, language, and power: Understanding relationships among personhood, literacy practices, and intertextuality. Journal of Literacy Research, 30(4), 449-487.

Erickson, F. (2004). Talk and social theory: Ecologies of speaking and listening in everyday life. Malden, MA: Polity.

Fairclough, N. (1995). Critical discourse analysis: The critical study of language. New York: Longman.

Gadsden, V.L., Davis, J.E., \& Artiles, A.J. (2009). Introduction: Risk, equity, and schooling: Transforming the discourse. Review of Research in Education, 33(1), vii-xi. doi:10.3102/0091732X08330002

Gebhard, M. (2002). Fast capitalism, school reform, and second language literacy practices. Canadian Modern Language Review, 59(1), $15-52$.

Gee, J.P. (1996). Social linguistics and literacies: Ideology in discourses (2nd ed.). London: Falmer.

Gee, J.P. (1999). An introduction to discourse analysis: Theory and method. New York: Routledge.

Gee, J.P. (2000a). The new literacy studies: From "socially situated" to the work of the social. In D. Barton, M. Hamilton, \& R. Ivanic (Eds.), Situated literacies: Reading and writing in context (pp. 180197). London: Routledge.

Gee, J.P. (2000b). Identity as an analytic lens for research in education. Review of Research in Education, 25(1), 99-125.

Gee, J.P. (2000c). New people in new worlds: Networks, the new capitalism and schools. In B. Cope \& M. Kalantzis (Eds.) Multiliteracies: Literacy learning and the design of social futures (pp. 41-66). London: Routledge.

Gee, J.P. (2000d). Teenagers in new times: A new literacy studies perspective. Journal of Adolescent \& Adult Literacy, 43(5), 412-420.

Gee, J.P. (2005a). Language in the science classroom: Academic social languages as the heart of school-based literacy. In R.K. Yerrick \& W.-M. Roth (Eds.), Establishing scientific classroom discourse communities: Multiple voices of teaching and learning research (pp. 19-38). Mahwah, NJ: Erlbaum.

Gee, J.P. (2005b). An introduction to discourse analysis: Theory and method (2nd ed.). New York: Routledge.

Gee, J., \& Green, J. (1998). Discourse analysis, learning, and social practice: A methodological study. Review of Research in Education, 23, 119-170.

Godley, A.J. (2003). Literacy learning as gendered identity work. Communication Education, 52(3-4), 273-285. doi:10.1080/0363452032000156244

Godley, A.J., Carpenter, B.D., \& Werner, C.A. (2007). "I'll speak in proper slang": Language ideologies in a daily editing activity. Reading Research Quarterly, 42(1), 100-131. doi:10.1598/ RRQ.42.1.4

Gomez, K. (2007). Negotiating discourses: Sixth-grade students' use of multiple science discourses during a science fair presentation. 
Linguistics and Education: An International Research Journal, 18(1), 41-64.

Graesser, A.C., Mills, K., \& Zwaan, R. (1997). Discourse comprehension. Annual Review of Psychology, 48, 163-189. doi:10.1146/ annurev.psych.48.1.163

Green, J.L., \& Wallat, C. (Eds.). (1981). Ethnography and language in educational settings (Vol. 5). In R.O. Freedle (Series Ed.), Advances in discourse processes. Norwood, NJ: Ablex.

Gutiérrez, K.D. (2008). Developing a sociocritical literacy in the third space. Reading Research Quarterly, 43(2), 148-164. doi:10.1598/ RRQ.43.2.3

Gutiérrez, K.D., Baquedano-López, P., \& Turner, M.G. (1997). Putting language back into language arts: When the radical middle meets the third space. Language Arts, 74(5), 368-378.

Gutiérrez, K.D., Morales, P.Z., \& Martinez, D.C. (2009). Remediating literacy: Culture, difference, and learning for students from nondominant communities. Review of Research in Education, 33(1), 212-245. doi:10.3102/0091732X08328267

Haneda, M. (2006). Becoming literate in a second language: Connecting home, community, and school literacy practices. Theory Into Practice, 45(4), 337-345. doi:10.1207/ s15430421tip4504_7

Hanrahan, M.U. (2006). Highlighting hybridity: A critical discourse analysis of teacher talk in science classrooms. Science Education, 90(1), 8-43. doi:10.1002/sce. 20087

Heath, S.B. (1983). Ways with words: Language, life, and work in communities and classrooms. New York: Cambridge University Press.

Heffernan, L., \& Lewison, M. (2005). What's lunch got to do with it? Critical literacy and the discourse of the lunchroom. Language Arts, 83(2), 107-117.

Hicks, D. (2005). Class readings: Story and discourse among girls in working-poor America. Anthropology \& Education Quarterly, 36(3), 212-229. doi:10.1525/aeq.2005.36.3.212

Hinchman, K.A., \& Young, J.P. (2001). Speaking but not being heard: Two adolescents negotiate classroom talk about text. Journal of Literacy Research, 33(2), 243-268.

Hines, M.B., \& Appleman, D. (2000). Multiple ways of knowing in literature classrooms. English Education, 32(2), 141-168.

Howarth, D. (2000). Discourse. Philadelphia: Open University Press.

Hyland, K. (2005). Stance and engagement: A model of interaction in academic discourse. Discourse Studies, 7(2), 173-192. doi:10.1177/1461445605050365

Ivanič, R. (1998). Writing and identity: The discoursal construction of identity in academic writing. Amsterdam: John Benjamin's.

Ivanič, R. (2004). Discourses of writing and learning to write. Language and Education, 18(3), 220-245. doi:10.1080/ 09500780408666877

Jacobs, G.E. (2004). Complicating contexts: Issues of methodology in researching the language and literacies of instant messaging. Reading Research Quarterly, 39(4), 394-406. doi:10.1598/ RRQ.39.4.3

Jacobs, G.E. (2006). Fast times and digital literacy: Participation roles and portfolio construction within Instant Messaging. Journal of Literacy Research, 38(2), 171-196. doi:10.1207/ s15548430jlr3802_3

Jewitt, C. (2008). Multimodality and literacy in school classrooms. Review of Research in Education, 32(1), 241-267. doi:10.3102/ $0091732 \times 07310586$

Johns, A.M. (2002). Genre in the classroom: Multiple perspectives. Mahwah, NJ: Erlbaum.

Johnson, G. (2002). Moving towards critical literacies in conversations about the teaching of English. The Australian Journal of Language and Literacy, 25(2), 49-60.

Johnstone, B. (2001). Discourse analysis. New York: Blackwell.
Jones, S. (2006). Language with an attitude: White girls performing class. Language Arts, 84(2), 114-124.

Juzwik, M.M. (2006). Performing curriculum: Building ethos through narratives in pedagogical discourse. Teachers College Record, 108(4), 489-528. doi:10.1111/j.1467-9620.2006.00659.x

Kahn, R., \& Kellner, D. (2005). Reconstructing technoliteracy: A multiple literacies approach. E-Learning, 2(3), 238-251. Retrieved September 8, 2009, from dx.doi.org/10.2304/elea.2005.2.3.4

Kinder, M. (1991). Playing with power in movies, television and video games: From Muppet Babies to Teenage Mutant Ninja Turtles. Berkeley: University of California Press.

Knoeller, C., \& Freedman, S. (1998). Voicing ourselves: Whose words we use when we talk about books. New York: SUNY Press.

Kramer-Dahl, A. (2004). Constructing adolescents differently: On the value of listening to Singapore youngsters talking popular culture texts. Linguistics and Education, 15(3), 217-241. doi:10.1016/j. linged.2004.12.005

Kress, G.R. (2003). Literacy in the new media age. London: Routledge.

Kress, G.R., \& Van Leeuwen, T. (2001). Multimodal discourse: The modes and media of contemporary communication. London: Edward Arnold

Lam, W.S.E. (2000). L2 literacy and the design of the self: A case study of a teenager writing on the Internet. TESOL Quarterly, 34(3), 457-482. doi:10.2307/3587739

Lam, W.S.E. (2006). Re-envisioning language, literacy, and the immigrant subject in new mediascapes. Pedagogies, 1(3), 171-195. doi:10.1207/s15544818ped0103_2

Lam, W.S.E. (2009). Multiliteracies on instant messaging in negotiating local, translocal, and transnational affiliations: A case of an adolescent immigrant. Reading Research Quarterly, 44(4), 377-397.

Larson, J., \& Irvine, P.D. (1999). "We call him Dr. King": Reciprocal distancing in urban classrooms. Language Arts, 76(5), 393-400.

Lea, M.R., \& Street, B.V. (2006). The "academic literacies" model: Theory and applications. Theory Into Practice, 45(4), 368-377. doi:10.1207/s15430421tip4504_11

Lee, S.H. (2008). An integrative framework for the analyses of argumentative/persuasive essays from an interpersonal perspective. Text \& Talk, 28(2), 239-270.

Lemke, J. (1995). Textual politics: Discourse and social dynamics. London: Taylor \& Francis.

Leung, C., \& Safford, K. (2005). Nontraditional students in higher education in the United Kingdom: English as an additional language and literacies. In B. Street (Ed.), Literacies across educational contexts: Mediating learning and teaching (pp. 303-324). Philadelphia: Caslon Publishing.

Lewis, C., \& Fabos, B. (2005). Instant messaging, literacies, and social identities Reading Research Quarterly, 40(4), 470-501.

Lillis, T.M. (2001). Student writing: Access, regulation, desire. London: Routledge.

Lonsdale, M., \& McCurry, D. (2004). Literacy in the new millennium. Adelaide, Australia: NCVER.

Love, K. (2000). The regulation of argumentative reasoning in pedagogic discourse. Discourse Studies, 2(4), 420-451. doi:10.1177/ 1461445600002004002

Love, K., \& Hamston, J. (2001). Out of the mouths of boys: A profile of boys committed to reading. The Australian Journal of Language and Literacy, 24(1), 31-48.

Luke, A. (2003). Literacy and the other: A sociological approach to literacy research and policy in multilingual societies. Reading Research Quarterly, 38(1), 132-141.

Luke, A., \& Freebody, P. (1997). Shaping the social practices of reading. In S. Muspratt, A. Luke, \& P. Freebody (Eds.), Constructing critical literacies (pp. 185-223). Cresskill, NJ: Hampton. 
Luke, C. (2003). Pedagogy, connectivity, multimodality, and interdisciplinarity. Reading Research Quarterly, 38(3), 397-403.

Luna, C. (2003). (Re)writing the discourses of schooling and of "learning disabilities": The development of critical literacy in a student action group. Reading \& Writing Quarterly, 19(3), 253280. doi:10.1080/10573560308211

Majors, Y.J. (2007). Narrations of cross-cultural encounters as interpretative frames for reading word and world. Discourse E Society, 18(4), 479-505. doi:10.1177/0957926507077424

Maloch, B. (2005a). Becoming a "WOW Reader": Context and continuity in a second grade classroom. Journal of Classroom Interaction, 40(1), 5-17.

Maloch, B. (2005b). Moments by which change is made: A crosscase exploration of teacher mediation and student participation in literacy events. Journal of Literacy Research, 37(1), 95-142. doi:10.1207/s15548430jlr3701_4

Mariage, T.V. (2000). Constructing educational possibilities: A sociolinguistic examination of meaning-making in "sharing chair." Learning Disability Quarterly, 23(2), 79-103. doi:10.2307/ 1511139

Martínez-Roldán, C.M. (2003). Building worlds and identities: A case study of the role of narratives in bilingual literature discussions. Research in the Teaching of English, 37(4), 491-526.

Martínez-Roldán, C.M., \& Malavé, G. (2004). Language ideologies mediating literacy and identity in bilingual contexts. Journal of Early Childhood Literacy, 4(2), 155-180. doi:10.1177/ 1468798404044514

Maybin, J. (2007). Literacy under and over the desk: Oppositions and heterogeneity. Language and Education, 21(6), 515-530. doi: $10.2167 / 1$ e 720.0

McDonald, L. (2004). Moving from reader response to critical reading: Developing 10-11-year-olds' ability as analytical readers of literary texts. Literacy, 38(1), 17-25. doi:10.1111/j.00340472.2004.03801004.x

McHoul, A., \& Luke, A. (1989). Discourse as language and politics: An introduction to the philology of political culture in Australia. Journal of Pragmatics, 13(3), 323-332. doi:10.1016/03782166(89)90057-X

Medina, C. (in press). "Reading across communities" in biliteracy practices: Examining translocal discourses and cultural flows in literature discussions. Reading Research Quarterly.

Mercer, N. (1995). The guided construction of knowledge: Talk amongst teachers and learners. Bristol, PA: Multilingual Matters.

Mercer, N. (2004). Sociocultural discourse analysis: Analysing classroom talk as a social mode of thinking. Journal of Applied Linguistics, 1(2), 137-168. doi:10.1558/japl.2004.1.2.137

Michaels, S. (1981). "Sharing Time": Children's narrative styles and differential access to literacy. Language in Society, 10(3), 423-442. doi:10.1017/S0047404500008861

Mills, S. (2004). Discourse: The new critical idiom. London: Routledge.

Minami, M. (2002). Culture-specific language styles: The development of oral narrative and literacy. Buffalo, NY: Multilingual Matters.

Moita-Lopes, L.P. (2006). Queering literacy teaching: Analyzing gay-themed discourses in a fifth-grade class in Brazil. Journal of Language, Identity, and Education, 5(1), 31-50. doi:10.1207/ s15327701jlie0501_3

Moje, E.B. (1997, Summer). Exploring discourse, subjectivity, and knowledge in chemistry class. Journal of Classroom Interaction, 32, $35-44$.

Moje, E.B., Ciechanowski, K.M., Kramer, K., Ellis, L., Carrillo, R., \& Callazo, T. (2004). Working toward a third space in content area literacy: An examination of everyday funds of knowledge and Discourse. Reading Research Quarterly, 39(1), 38-70. doi:10.1598/ RRQ.39.1.4
Moje, E.B., \& Luke, A. (2009). Literacy and identity: Examining the metaphors in history and contemporary research. Reading Research Quarterly, 44(4), 415-437.

Moni, K., van Kraayenoord, C.E., \& Baker, C.D. (2003). An investigation of discourses of literacy assessment in two first year high school English classrooms. Australian Journal of Language and Literacy, 26(1), 67-83.

New London Group. (1996). A pedagogy of multiliteracies: Designing social futures. Harvard Educational Review, 66(1), 60-92.

Newman, M. (2005). Rap as literacy: A genre analysis of hip-hop ciphers. Text, 25(3), 399-436.

Nichols, S. (2002). Parents' construction of their children as gendered, literate subjects: A critical discourse analysis. Journal of Early Childhood Literacy, 2(2), 123-144.

O'Connor, M.C., \& Michaels, S. (1993). Aligning academic task and participation status through revoicing: Analysis of a classroom discourse strategy. Anthropology \& Education Quarterly, 24(4), 318-335. doi:10.1525/aeq.1993.24.4.04x0063k

Olson, K. (2007). Lost opportunities to learn: The effects of education policy on primary language instruction for English learners. Linguistics and Education, 18(2), 121-141. doi:10.1016/j. linged.2007.07.001

Orellana, M.F. (1996). Negotiating power through language in classroom meetings. Linguistics and Education, 8(4), 335-365. doi:10.1016/S0898-5898(96)90016-9

Paltridge, B. (2006). Discourse analysis: An introduction. New York: Continuum.

Paul, P.V., \& Wang, Y. (2006). Literate thought and multiple literacies. Theory Into Practice, 45(4), 304-310. doi:10.1207/ s15430421tip4504_3

Payne, R. (2005). A framework for understanding poverty. Highlands, TX: Aha! Process.

Perry, T.B. (2006). Multiple literacies and middle school students. Theory Into Practice, 45(4), 328-336. doi:10.1207/ s15430421tip4504_6

Peterson, S., \& Calovini, T. (2004). Social ideologies in grade eight students' conversation and narrative writing. Linguistics and Education, 15(1-2), 121-139. doi:10.1016/j.linged.2004.12.001

Phelps, S., \& Weaver, D. (1999). Public and personal voices in adolescents' classroom talk. Journal of Literacy Research, 31(3), 321-354.

Poole, D. (1990). Discourse analysis in ethnographic research. Annual Review of Applied Linguistics, 11, 42-56.

Poole, D. (2003). Linguistic connections between co-occurring speech and writing in a classroom literacy event. Discourse Processes, 35(2), 103-134. doi:10.1207/S15326950DP3502_2

Potter, A. (2004). Interactive rhetoric for online learning environments. The Internet and Higher Education, 7(3), 183-198. doi:10.1016/j.iheduc.2004.06.002

Potter, J. (1997). Discourse analysis as a way of analysing naturally occurring talk. In D. Silverman (Ed.), Qualitative research: Theory, method and practice (pp. 200-221). London: Sage.

Potter, J., \& Wetherell, M. (1994). Analyzing discourse. In A. Bryman \& R.G. Burgess (Eds.), Analyzing qualitative data (pp. 47-66). London: Routledge.

Ravid, D., \& Berman, R. (2006). Information density in the development of spoken and written narratives in English and Hebrew. Discourse Processes, 41(2), 117-149. doi:10.1207/ s15326950dp4102_2

Razfar, A. (2005). Language ideologies in practice: Repair and classroom discourse. Linguistics and Education, 16(4), 404-424. doi:10.1016/j.linged.2006.04.001

Reveles, J.M., Cordova, R., \& Kelly, G.J. (2004). Science literacy and academic identity formulation. Journal of Research in Science Teaching, 41(10), 1111-1144. doi:10.1002/tea.20041 
Rex, L.A. (2000). Judy constructs a genuine question: A case for interactional inclusion. Teaching and Teacher Education, 16(3), 315-333. doi:10.1016/S0742-051X(99)00064-5

Rex, L.A. (2001). The remaking of a high school reader. Reading Research Quarterly, 36(3), 288-314. doi:10.1598/RRQ.36.3.3

Rex, L.A. (Ed.). (2006a). Discourse of opportunity: How talk in learning situations creates and constrains. Cresskill, NJ: Hampton Press.

Rex, L.A. (2006b). Acting "cool" and "appropriate": Toward a framework for considering literacy classroom interactions when race is a factor. Journal of Literacy Research, 38(3), 275-325. doi:10.1207/ s15548430jlr3803_2

Rex, L.A., \& Green, J L. (2007). Classroom discourse and interaction, Reading across the traditions. In B. Spolsky \& F.M. Hult (Eds.), International Handbook of Educational Linguistics (pp. 571584). London: Blackwell.

Rex, L.A., \& McEachen, D. (1999). "If anything is odd, inappropriate, confusing, or boring, it's probably important": The emergence of inclusive academic literacy through English classroom discussion practices. Research in the Teaching of English, 34(1), 65-129.

Richardson, E. (2007). "She was workin like foreal": Critical literacy and discourse practices of African American females in the age of hip hop. Discourse E Society, 18(6), 789-809. doi:10.1177/0957926507082197

Roberts, C., \& Sarangi, S. (2001). "Like you're living two lives in one go": Negotiating different social conditions for classroom learning in a further education context in England. In M. Heller \& M. Martin-Jones (Eds.), Voices of authority: Education and linguistic difference (pp. 171-192). Westport, CT: Ablex.

Rogers, R. (2003). A critical discourse analysis of family literacy practices: Power in and out of print. Mahwah, NJ: Erlbaum.

Rogers, R. (2004). Storied selves: A critical discourse analysis of adult learners' literate lives. Reading Research Quarterly, 39(3), 272-305. doi:10.1598/RRQ.39.3.2

Rogers, R., Malancharuvil-Berkes, E., \& Mosley, M., Hui, D., \& Joseph, G.O. (2005). Critical discourse analysis in education: A review of the literature. Review of Educational Research, 75(3), 365-416. doi:10.3102/00346543075003365

Rogers, R., \& Mosley, M. (2006). Racial literacy in a second-grade classroom: Critical race theory, whiteness studies, and literacy. Reading Research Quarterly, 41(4), 462-495. doi:10.1598/ RRQ.41.4.3

Rogers, T., Tyson, C., \& Marshall, E. (2000). Living dialogues in one neighborhood: Moving toward understanding across discourses and practices of literacy and schooling. Journal of Literacy Research, 32(1), 1-24.

Schleppegrell, M.J. (2004). The language of schooling: A functional linguistics perspective. Mahwah, NJ: Erlbaum.

Soep, E. (2006). Beyond literacy and voice in youth media production. McGill Journal of Education, 41(3), 197-213.

Steinkuehler, C.A. (2006). Massively multiplayer online video gaming as participation in a discourse. Mind, Culture, and Activity, 13(1), 38-52. doi:10.1207/s15327884mcal301_4

Street, B. (1984). Literacy in theory and practice. Cambridge: Cambridge University Press.

Street, B. (1993). Cross-cultural approaches to literacy. Cambridge: Cambridge University Press.
Street, B. (1995). Social literacies: Critical approaches to literacy in development, ethnography, and education. Reading, MA: AddisonWesley.

Tannen, D. (1989). Talking voices: Repetition, dialogue, and imagery in conversational discourse. Cambridge: Cambridge University Press.

Thesen, L. (2001). Modes, literacies and power: A university case study. Language and Education, 15(2-3), 132-145. doi:10.1080/ 09500780108666806

Thonus, T. (1999). Dominance in academic writing tutorials: Gender, language proficiency, and the offering of suggestions. Discourse $\mathcal{E}$ Society, 10(2), 225-248. doi:10.1177/0957926599010002005

van Leeuwen, T. (2008). Discourse and practice: New tools for critical discourse analysis. New York: Oxford University Press.

Van Sluys, K., Lewison, M., \& Flint, A.S. (2006). Researching critical literacy: A critical study of analysis of classroom discourse. Journal of Literacy Research, 38(2), 197-233. doi:10.1207/ s15548430jlr3802_4

Weinstein, S. (2006). A love for the thing: The pleasures of rap as a literate practice. Journal of Adolescent \& Adult Literacy, 50(4), 270-281. doi:10.1598/JAAL.50.4.3

Wesley, K. (2000). The ill effects of the five paragraph theme. English Journal, 90(1), 57-60. doi:10.2307/821732

White, N.L. (2002). Discourses of power: An analysis of homework events. Linguistics and Education, 13(1), 89-135. doi:10.1016/ S0898-5898(01)00066-3

Wohlwend, K. (2009). Damsels in discourse: Girls consuming and producing identity texts through Disney princess play. Reading Research Quarterly, 44(1), 57-83. doi:10.1598/RRQ.44.1.3

Wolfe, M.B., \& Goldman, S.R. (2005). Relations between adolescents' text processing and reasoning. Cognition and Instruction, 23(4), 467-502. doi:10.1207/s1532690xci2304_2

Woods, N. (2006). Describing discourse: A practical guide to discourse analysis. New York: Hodder Arnold.

Woude, J.V., \& Barton, E. (2003). Interactional sequences in shared book-reading between parents and children with histories of language delay. Journal of Early Childhood Literacy, 3(3), 249-273. doi:10.1177/1468798403033003

Young, J.P. (2000). Boy talk: Critical literacy and masculinities. Research Reading Quarterly, 35(3), 312-337. doi:10.1598/ RRQ.35.3.1

Lesley A. Rex is professor of education and cochair of the Joint Program of English and Education at the University of Michigan, Ann Arbor, USA.

Heather Thomson is a recent graduate of the Joint Program of English and Education at the University of Michigan, Ann Arbor, USA.

Mike Bunn, Bethany A. Davila, Hannah A. Dickinson, Amy Carpenter Ford, Chris Gerben, and Melinda J. McBee Orzulak are doctoral candidates in the Joint Program of English and Education at the University of Michigan.

All authors can be reached via the program's assistant, Jeanie Laubenthal, at laubenth@umich.edu. 